\title{
The impact of the institutional environment on the value relevance of fair values
}

\author{
Peter Fiechter \\ University of Neuchatel \\ Zoltan Novotny-Farkas \\ Lancaster University
}

\begin{abstract}
Most prior studies attribute valuation discounts on certain fair valued assets to measurement error or bias. We argue that institutional differences across countries (e.g., information environment or market sophistication) affect investors' ability to process and impound fair value information in their valuation. We predict that the impact of the institutional environment on the value relevance is particularly pronounced for reported fair values of assets designated at fair value through profit or loss (hereafter, "FVO assets"), for which investor experience is lowest and complexity is highest. Using a global sample of IFRS banks, we find that FVO assets are generally less value relevant than held-for-trading assets (HFT) and available-for-sale assets (AFS). By partitioning countries into market- and bank-based economies to proxy for institutional differences, we find that the valuation discount on FVO assets is more pronounced in bank-based economies. Additional tests suggest that this valuation discount is attenuated by a richer firm-level information environment and the presence of institutional investors with fair value experience. Robustness analyses show that our findings are not solely attributable to differences in fair value measurement, fair value quality, or asset type composition.
\end{abstract}

Keywords: Fair Value Accounting, International Financial Reporting Standards (IFRS), Value Relevance, Institutional Accounting, Information Environment

JEL Classifications: G21, M41

We thank Lakshmanan Shivakumar (the editor), an anonymous reviewer, Mary Barth, Rick Cuijpers, Markus Hitz, Leslie Hodder, Wayne Landsman, Mari Paananen, Ken Peasnell, Annelies Renders, Ann Vanstraelen, Steve Young, and workshop participants at Lancaster University, University of Zurich, Maastricht University, University of Göttingen, Brunel University, Cass Business School, the 2011 EAA Annual Congress, and the 2011 AAA Annual Conference for helpful comments. We also thank Thomas Erdosi and Matthias Wyss for research assistance. 


\section{Introduction}

The literature investigating the value relevance of fair values primarily focuses on fair value measurement issues, providing evidence that this value relevance decreases with measurement error or bias (e.g., Barth 1994; Barth et al. 1996; Eccher et al. 1996; Song et al. 2010). Studies examining other determinants of the value relevance of fair values are scarce: Some show that this value relevance increases when fair values are expected to be realized through sale or settlement in the short term (Park et al. 1999) and when they reflect the expected opportunity costs and benefits of holding specific cash flow rights of financial instruments (Evans et al. 2014). In an experimental setting, Koonce et al. (2011) find that investors judge fair value as relevant when the instrument is expected to be sold or settled soon, not held to maturity. Finally, Skinner (1996) points out that the complexity of certain fair values (i.e., bank derivatives and employee stock options) can limit the ability of market participants to properly process and impound fair value information in their valuation.

We examine whether international variation in institutional factors plays a role in determining the value relevance of reported fair values beyond fair value measurement. Since the worldwide adoption of IFRS around 2005, banks are largely affected by the application of IAS 39 Financial Instruments: Recognition and Measurement, which provides three fair value categories for financial assets: held-for-trading (HFT), available-for-sale (AFS), and the fair value option $(\mathrm{FVO}){ }^{1}$ The idea behind the three fair value categories is to inform financial

1 We focus on FVO assets rather than FVO liabilities because the interpretation of coefficient estimates for FVO liabilities is difficult, as it is not clear whether and how investors impound own credit risk (OCR) adjustments. In addition, our descriptive statistics (see Table 2) suggest that the FVO is selected less frequently for liabilities than for assets. However, for completeness and comparability, we also include financial liabilities in our empirical analyses, and the results for liabilities are consistent with our main inferences. 
statement users about managements' intent on how value will be realized from financial instruments (e.g., FASB 1993; Park et al. 1999; IASB 2006). However, this intent-based classification assumes that market participants properly process and impound this information in their valuation.

In an international setting, the ability to process fair value information likely varies with institutional factors, such as the country-level information environment and market sophistication. However, institutional factors might have a different impact on each of the three fair value categories. In particular, we expect the institutional effect to be most pronounced for FVO assets, because (a) experience is lowest for the FVO, which-after several amendmentswas effective as of January 1, 2006; (b) the intent underlying banks' application of the FVO can be unclear (BCBS 2006a); and (c) the FVO was the most controversially debated fair value category among practitioners, regulators, and standard setters (ECB 2004, Fiechter 2011). Therefore, the FVO potentially raises complexity for financial statement users. ${ }^{2}$

To investigate whether and how the value relevance of fair values varies with the institutional environment, we classify countries into market- and bank-based economies (Ali and Hwang 2000; Beck and Levine 2002). The institutional features of market-based economies are geared more towards the information needs of arm's length investors (e.g., Ali and Hwang 2000; Leuz 2010). Specifically, high stock market development, high disclosure standards, and strong information environments likely ensure that capital market participants properly process and

2 During the standard setting process, $9 \%, 15 \%$, and $18 \%$ of the comment letters explicitly expressed concerns that the application intent underlying the FVO is unclear, economically identical transactions can be differently accounted for under the FVO, and the FVO might be applied inappropriately, respectively. In the second round, $28 \%$ of all comment letters argued that the FVO is simply too complex (source: own data analysis of comment letters to revision of IAS 39 in 2002 and 2004) 
price fair value information. In contrast, in bank-based economies with less developed stock markets and weaker information environments, investors might have difficulties in processing fair value information. However, to the extent that bank-based economies have weaker enforcement, the institutional environment could also impact measurement error (or bias) and, in turn, the value relevance of fair values.

We hand-collect data on reported fair values of financial instruments for IFRS banks from 2006 through 2009, resulting in a global sample of 907 bank-years from 46 countries. $^{3}$ Applying the research design of previous studies (e.g., Landsman et al. 2008; Song et al. 2010), we test for differences in value relevance across both fair value categories and institutional environments. Our setting has two main advantages: First, because all three fair value categories are recognized fair values, differences in value relevance cannot be attributable to a lesser reliability of disclosed fair values than recognized fair values. Second, we can compare estimated valuation coefficients across two dimensions: fair value categories and institutional environment.

We find that FVO assets are generally less value relevant than HFT and AFS assets. The valuation coefficient on FVO assets is particularly pronounced in bank-based economies. In contrast, the value relevance of HFT and AFS assets does not significantly vary across institutional environments. This finding increases confidence that the estimated valuation discount for FVO assets in bank-based economies is not solely attributable to a generally lower valuation of accounting fundamentals in such economies. However, at this stage, we cannot yet determine whether measurement error or differences in the ability to properly process fair value information contribute to these results.

3 The FVO (in its revised and thus internationally comparable version) is applicable for annual periods on or after January 1, 2006. Therefore, the earliest data on the FVO was available as of December 31, 2006. 
To investigate whether the observed differences in value relevance are linked to differences in investors' ability to process fair value information, we perform two additional tests exploiting firm-specific within-country variation. Specifically, we address two potential frictions: the information environment and investors' experience with fair values. First, we examine whether firm-specific transparency improves value relevance, because recent empirical studies show that firm-specific transparency matters most in otherwise opaque (country-level) information environments (Maffett 2012; Lang et al. 2012). We find that a stronger firm-level information environment results in a higher value relevance of FVO assets in bank-based economies, suggesting that the weaker country-level information environment in such economies limits investors' ability to properly process fair value information of FVO assets.

Second, we examine whether the value relevance of fair values varies with institutional investors' experience with the use of fair values. Specifically, we argue that because of Nordic investors' longer experience with fair value accounting, these investors should be better able to understand FVO assets. Our results are consistent with this prediction. In particular, while variation in institutional investor holdings generally does not impact value relevance, we find that larger holdings by Nordic institutional investors significantly increase the value relevance of the FVO in bank-based economies. This finding supports the notion that more experience with fair values improves investors' ability to process fair value information.

We run several additional tests to rule out alternative explanations, in particular that differences in measurement error or fair value quality are driving our results. First, to mitigate concerns that measurement error may be systematically higher for FVO assets in bank-based economies, we test whether the distribution of the valuation inputs (i.e., Levels 1, 2, and 3) significantly differs across both fair value categories and institutional environments. Univariate 
comparisons reveal that the proportion of Level 3 relative to Level 1 and 2 inputs is higher (lower) for FVO assets than for HFT (AFS) assets. While the proportion of Level 3 inputs for FVO assets is lower in bank-based than in market-based economies, the proportion of Level 2 inputs is higher, possibly explaining some of the valuation discount of FVO assets in bank-based economies. Therefore, we also perform multivariate tests by holding constant the level of fair value measurement (i.e., Level 1), for which measurement error is presumably lowest (Song et al. 2010, Goh et al. 2015). Consistent with our main findings, we find a valuation discount only for Level 1 FVO assets, and the discount is larger in bank-based economies. However, the valuation discount on the FVO is smaller than in the primary findings, indicating that fair value measurement explains some but not all of the lower value relevance.

Second, to investigate whether fair value quality differs between market- and bank-based economies, we test the ability of fair values to reflect the underlying cash flow and risk characteristics of FVO assets. Following Altamuro and Zhang (2013), we test whether FVO valuation multiples reflect the persistence of underlying cash flows (i.e., interest, dividends, and net gains from asset disposals). We find that, in both financial systems, FVO valuation multiples are significantly higher when the underlying cash flows are more (less) persistent (risky). This finding mitigates the concern that differences in the quality of fair values are driving our main results.

We contribute to the literature by providing evidence that, beyond fair value measurement issues, other factors also play a significant role in determining the value relevance of fair values. Our findings suggest that international variation in investors' ability to process fair value information impacts the value relevance of fair values. Specifically, weak information environments and little experience with certain fair valued assets limit investors' processing of 
fair value information. Therefore, we provide empirical support for Skinner's (1996) argument and show that information processing is not only an issue for disclosed but also for recognized fair values (e.g., Bernard and Schipper 1994; Schipper 2007). In addition, on the descriptive level, we provide evidence on the extent of fair value accounting and the use of fair value measurement inputs for a comprehensive international sample of banks. Consistent with prior small sample evidence (Laux and Leuz 2010), we show that, on average, banks measure a relatively small portion of their assets at fair value, and even a smaller portion at fair value through profit or loss - a fact that the debate on fair value accounting often neglects.

The remainder of the paper is organized as follows. Section II reviews relevant prior work, introduces the different fair value categories under IAS 39, and develops predictions. Section III outlines the research design, and Section IV describes the sample and data. Section V presents empirical results and Section VI includes additional analyses and robustness checks. Section VII concludes.

\section{Background and predictions}

\subsection{Literature review}

Prior literature focuses on the role of measurement issues (estimation error or bias) as a main source of variation in the value relevance of fair values. For a sample of U.S. banks, Barth (1994) provides evidence that the fair values of investment securities are incrementally associated with bank share prices. Several studies assess the value relevance of disclosed fair values of different types of bank assets: investment securities, loans, deposits, and long-term debt (Barth et al. (1996), Eccher et al. (1996), and Nelson (1996)). They find that the fair values 
of investment securities are incrementally informative, whereas the findings for the value relevance of loans and deposits are inconclusive.

While early research examined the value relevance of disclosed fair values, more recent studies focus on recognized fair values. Ahmed et al. (2006) find that recognized fair values of derivatives are value relevant, whereas disclosed fair values are not. Kolev (2009), Song et al. (2010), and Goh et al. (2015) examine whether the value relevance of fair values varies with valuation inputs (i.e., Levels 1, 2, and 3). As Level 3 fair values are based on unobservable inputs, they might be subject to management discretion. Therefore, these studies predict and find that investors discount Level 3 fair value estimates.

Studies investigating other determinants (than measurement issues) of the value relevance of fair values are scarce. Park et al. (1999) analyze whether intent-based classification reflects value-relevant information. They find that the fair value differences of banks' AFS securities are more value relevant than the fair value differences of held-to-maturity (HTM) securities, because managers intend to sell AFS securities in the short term. However, the result of Park et al. (1999) might be driven by AFS fair value changes being recognized in financial statements, whereas the fair values of HTM securities are only disclosed (Ryan 1999). In an experimental setting, Koonce et al. (2011) find that fair values of HTM securities are not relevant for valuation, because investors might not perceive such unrealized fair value gains and losses as forgone opportunities. Evans et al. (2014) predict and find that the differential pricing of fair value information is also related to differential predictive ability of fair values, not only to measurement error.

These studies examine the value relevance of fair values in the U.S. - a setting with welldeveloped capital markets and rich disclosure and information environments. Thus investors can 
presumably properly process fair value information (Skinner 1996). However, in an international setting, institutional factors likely influence the properties of fair values. For example, De Fond et al. (2015) find an increase in crash risk post IAS 39 adoption only for banks in countries with weak banking regulation. In addition, Ball et al. (2015) find that the use of fair values reduces the relevance of accounting numbers for debt contracting. ${ }^{4}$

Few studies examine the value relevance of fair values in an international setting, and most of them focus on non-financial assets. For example, Müller et al. (2015) find for a sample of EU real estate firms that disclosed fair values have a lower association with equity prices than recognized fair values. The only study investigating the value relevance of financial assets, at least indirectly, is Barth et al. (2014) who provide evidence that net income adjustments related to IAS 39 are incrementally value relevant for financial firms but not for non-financial firms. The authors attribute this finding to the greater use of fair values under IAS 39 than under domestic GAAP, but do not directly test this argument. In this paper, we specifically test the value relevance of recognized fair values across different categories and institutional environments. We argue that the ability to process fair value information varies with institutional factors such as the country-level information environment and investors' experience with fair values, in turn affecting the value relevance of fair values.

\subsection{Fair value accounting under IAS 39}

The worldwide introduction of IFRS yielded a significant expansion in fair value accounting. While the trading books of banks were measured at fair value (or at the lower of cost

4 For an extensive review of the IFRS literature on fair value accounting, see Section 9.1 in the survey of De George et al. (2016). 
or market value) in most countries under their local GAAPs, IFRS allow or require fair value measurement for a substantial part of the banking book, which previously was carried at amortized cost (Matherat 2008). IAS 39 Financial Instruments: Recognition and Measurement provides three fair value categories: HFT, FVO, and AFS. The three fair value categories differ in the conditions for their application and the recognition of unrealized fair value gains or losses.

HFT assets are measured at fair value with all changes in fair value recognized in the income statement. According to IAS 39, paragraph 9 (IASB 2006), a financial asset is defined as trading if it is principally acquired to sell in the near term. While non-hedging derivatives are always categorized as HFT, firms have some leeway on how they interpret the phrase "principally acquired to sell in the near term" for non-derivative financial assets. Thus, classifying a security as HFT generally conveys the information that its fair value gains and losses are (intended) to be realized in the short term.

Upon initial recognition, entities can choose to designate a financial asset for measurement at fair value through profit or loss $(\mathrm{FVO}) .{ }^{5}$ When introducing the FVO, the IASB's main objective was to provide entities with an alternative to hedge accounting, thereby alleviating accounting mismatch issues that arise from the mixed measurement model. However, although using the FVO can potentially reduce accounting mismatches, at least three drawbacks exist. First, the optional nature of the FVO leads to less comparability within a bank and across banks, as similar (or identical) economic transactions are differently measured according to the

5 The FVO can be elected if one of the following three criteria is satisfied (IASB, 2006): (1) the application of the FVO eliminates or significantly reduces accounting mismatches; or (2) a group of financial instruments is managed and its performance is evaluated on a fair value basis; or (3) a financial instrument contains one or more substantive embedded derivatives. Under IAS 39, there are no transition provisions for the application of the FVO such as under FAS 159 (FASB 2007) so that only newly recognized positions are eligible for the FVO. Therefore, strategical election of the FVO as shown by Song (2008) is not possible. 
subjective managerial intent. Second, the FVO may be applied inconsistent with the IASB's stated intent of reducing accounting mismatches. Related, prudential supervisors are concerned about inappropriate FVO application (ECB 2004; BCBS 2006a). Third, even when the FVO is applied consistent with the IASB's intent, investors might not know the extent to which an item is economically hedged or what that item is. These issues create complexity for financial statements users.

AFS is a residual category for financial assets under IAS 39. Fair value changes of AFS assets are recognized in other comprehensive income unless assets are sold or there is objective evidence of impairment. Banks usually hold AFS assets for an indefinite period of time. AFS assets may be held until maturity or sold earlier to manage interest rate risks, prepayment risks, or liquidity needs. However, certain accounting rules for AFS — particularly the different impairment rules for debt and equity securities — can create application problems (ESMA 2010; IASB 2011, para. BC 5.25b).

\subsection{Institutional environment and the value relevance of fair values}

Underlying the intent-based classification of financial instruments is the idea that it provides relevant and useful information for evaluating a firm's investment strategy and performance (e.g., FASB 1993; Park et al. 1999; IASB 2006). Whether managerial intent conveyed by asset classifications matters for valuation purposes is debatable. Some argue and find that when assets are held to maturity and contractual cash flows are collected, fair values are not relevant (Park et al. 1999; Koonce et al. 2011). Others counter that, even when assets are held until maturity, fair values are relevant, because they inform investors about the opportunity costs and benefits of holding these assets below or above market rates (Ryan 1999; Evans et al. 2014). 
In a perfect world, absent measurement error and bias, fair values should be value relevant regardless of asset categorization and managerial intent. However, in an international setting, we argue that variation in institutional features across countries likely affects investors' ability to process fair value information for two main reasons. First, investors' ability to process this information might be complicated by the significant variation across countries in the quantity and the quality of disclosures related to financial instruments (Bischof 2009) and, more generally, the strength of information environment (e.g., Maffett 2012). For example, understanding why a bank elects the FVO is important. If the FVO alleviates accounting mismatches, further information is relevant on which risks are hedged and the effectiveness of the hedge. However, such disclosures (a) are neither standardized nor complete in international banks' financial statements, and (b) likely vary across countries.

Second, investors' experience with the use of fair value information beyond the trading book is limited in many institutional environments. A prominent exception is Denmark where investors are likely to be more accustomed to fair values, because banks applied mark-to-market accounting to a substantial portion of financial assets long before IFRS adoption (Bernard et al. 1995). Norway and Sweden extended the use of fair value accounting for banks even before the adoption of IFRS (e.g., Gjerde et al. 2011). Prior studies' findings suggest that experience with fair value reporting matters for the pricing of fair value-related information (Chambers et al. 2007; Dong et al. 2014).

To test the impact of institutional environment on the value relevance of fair values, we classify countries into market-based and bank-based financial systems (Ali and Hwang 2000, Beck and Levine 2002). This country clustering captures various institutional features (e.g., 
stock market development, disclosure rules, or enforcement) that likely affect investors' ability to process fair value information. ${ }^{6}$

Market-based economies are characterized by a stronger development of stock markets relative to bank-based economies. Contracting parties operate at arm's length, and information asymmetries are resolved by public disclosure (e.g., Ali and Hwang 2000, Beck and Levine 2002). A stronger country-level information environment (e.g., more disclosure or broader information dissemination) likely improves investors' ability to process fair value information. In contrast, in bank-based economies, the central role of banks in allocating resources reduces the need for public disclosure, resulting in a generally weaker information environment. Moreover, because fair value accounting limits contractibility (Ball et al. 2015), investors' use of and experience with fair values are likely lower in the more debt-reliant bank-based economies. Finally, given the lower number of institutional investors and professional information intermediaries (e.g., analysts), investors' ability and comfort in using fair value information is likely lower in bank-based economies. ${ }^{7}$

To the extent that investors in market-based economies properly process fair value information, we should not observe substantial differences in value relevance across fair value categories. However, we expect that the institutional features of bank-based economies limit investors' ability to properly process fair value information, particularly for FVO assets, for which familiarity is lowest and complexity is highest.

6 We do not use the Ball et al. (2000) dichotomous classification of countries into code law versus common law systems, because all countries in our sample apply IFRS. We also do not classify countries into outsider and insider economies (Leuz et al. 2003), because relevant data are missing for numerous countries in our sample.

7 Indirect evidence of professional information intermediaries having more comfort in using and processing fair values is provided in Bischof et al. (2014), who show that analysts specifically demand fair value information during conference calls, particularly during the crisis period and when fair value related disclosure is weak. 
To more directly attribute potential differences in value relevance to country-level frictions (i.e., weak information environment and little fair value experience), we next investigate firmspecific variation in information environment and fair value experience. First, given that firmspecific transparency matters most in otherwise opaque environments (Maffett 2012; Lang et al. 2012), we predict that a high bank-specific information environment increases the value relevance of reported fair values, particularly that of FVO assets in bank-based economies.

Second, to more directly test whether experience with recognized fair values drives differences in value relevance, we exploit variation in institutional investor holdings within our country clusters. Following previous literature (e.g., Balsam et al. 2000, Bartov et al. 2000, Collins et al. 2003), we use institutional investor holdings as a proxy for investor sophistication. More sophisticated investors should be better able to process fair value information. However, particularly in bank-based economies, even institutional shareholders may lack experience with fair values, especially the FVO. Therefore, in further tests, we use the presence of Nordic institutional shareholders as a proxy for investors' experience with fair values, because these shareholders have a long history of using fair values. Following the logic of our previous predictions, we expect the effect of institutional shareholders' experience to be most pronounced for the FVO in bank-based economies.

\section{Research design}

\subsection{Measurement of the financial system}

Following Beck and Levine (2002), we use the indicator variable Financial_Structure to distinguish between market- and bank-based economies. We first calculate Structure_Aggregate that captures the importance of stock markets relative to the banking sector in a country. We 
construct this variable as the first principal component of two variables that capture the comparative activity and size of stock markets relative to banks in the economy. The first variable, Structure_Activity, is the log of the ratio of value traded (Value_Traded) to bank credit (Bank_Credit). Value_Traded equals the value of stock transactions as a share of the gross domestic product (GDP). Bank_Credit represents the claims of the banking sector on the private sector as a share of GDP. The second variable Structure_Size is the log of the ratio of Market_Capitalization to Bank_Credit.Market_Capitalization is a proxy for the size of the stock market calculated as the value of listed shares divided by GDP. We average data for Structure_Aggregate from 1995 to 2004 (source: World Bank $^{8}$ ). ${ }^{9}$ Finally, we define Financial_Structure equal to 1 (i.e., market-based) if Structure_Aggregate for a country is above the sample median, and 0 (i.e., bank-based) otherwise.

\subsection{Value relevance of fair values across institutional environments}

Following prior value relevance literature (e.g., Barth et al. 2001; Landsman et al. 2008; Song et al. 2010; and Goh et al. 2015), we regress share price on reported balance sheet values and net income:

$$
\begin{aligned}
P R I C E_{\mathrm{it}}= & \beta_{0}+\beta_{1} F V O A \_P S_{\mathrm{it}}+\beta_{2} H F T A_{-} P S_{\mathrm{it}}+\beta_{3} A F S_{-} P S_{\mathrm{it}}+\beta_{4} O A \_P S_{\mathrm{it}}+\beta_{5} F V O L \_P S_{\mathrm{it}}+ \\
& \beta_{6} H F T L \_P S_{\mathrm{it}}+\beta_{7} O L \_P S_{\mathrm{it}}+\beta_{8} N I \_P S_{\mathrm{it}}+Y_{e}{ }_{2}+\text { Country }_{\mathrm{i}}+\varepsilon_{\mathrm{it}}
\end{aligned}
$$

8 The data can be downloaded at: http://econ.worldbank.org/WBSITE/EXTERNAL/EXTDEC/EXTRESEARCH/0,,contentMDK:20696167 page PK:64214825 piPK:64214943 theSitePK:469382,00.html. We use the November 2013 version of the dataset.

9 Following Beck and Levine (2002), we average the data over a 10-year period. We use a 10-year period that ends just before the worldwide introduction of IFRS; thereby we create an ex ante classification of countries that is neither affected by macroeconomic effects of IFRS adoption nor influenced by the financial crisis. However, our inferences hold when we use alternative, more recent periods to calculate Structure_Aggregate. 
PRICE is the market value of equity as of March 31. FVOA_PS, HFTA_PS, and AFS_PS are FVO assets, HFT assets, and AFS assets, respectively, as of December 31.OA_PS are non-fair value assets as of December 31. FVOL_PS and HFTL_PS are FVO liabilities and HFT liabilities, respectively, as of December 31. $O L \_P S$ are non-fair value liabilities as of December 31. NI_PS is the net income for the financial year. We scale all variables by the number of outstanding shares (Barth and Clinch 2009), and we denominate values in U.S. Dollars (USD).

For the main tests, we partition the sample into market- and bank-based economies, and we separately estimate Equation (1) using OLS. ${ }^{10}$ Following Nelson (1996) and Landsman et al. (2008), we use March 31 share prices as the dependent variable, whereas our explanatory variables are from December 31 of the previous year. Accordingly, we assume that the information of the annual report is available to investors by March $31 .^{11}$ As we pool observations across years, we use heteroskedasticity-robust standard errors that are clustered by bank (Rogers 1993). ${ }^{12}$ To control for differences across years, we include year dummies for all years except the base year 2006. To control for country-specific differences in bank valuation beyond the market structure, we include country fixed effects throughout the analyses. ${ }^{13}$

10 We partition the sample instead of using interaction terms, as we use both sample partitions and interaction terms for the additional tests on the role of the firm-specific information environment and institutional investors. However, our main inferences hold when we use interaction terms between Financial_Structure and FVO_PS, HFTA_PS, and $A F S \_P S$, respectively (see also Section V).

11 We do not use share prices later than March 31, as new information in connection with the first quarter earnings announcements may be available to investors.

12 When using standard errors clustered by country, our inferences remain similar, although this clustering changes the significance levels of some coefficients.

13 The regression results remain virtually constant when we control for differences in bank business models (i.e., regional, savings and loans, money center, and investment banks). In addition, the findings hold when we exclude investment banks from the sample. 


\subsection{The role of firm-level information environment and institutional investors}

To test the effect of firm-level information environment on value relevance of fair values, we extend Equation (1) by the variable High_Info and interaction terms between High_Info and FVOA_PS, HFTA_PS, and AFS_PS, respectively (Equation 2). ${ }^{14}$ High_Info equals 1 if a bank has both above sample median analyst following (\#Analysts) and above sample median market value of equity (MV_Equity), and 0 otherwise. ${ }^{15}$ To the extent that high-quality firm-level information environment improves investors' ability to process fair values, we expect positive coefficients on the interaction terms, particularly for FVO assets in bank-based economies.

$$
\begin{aligned}
P R I C E_{i t}= & \beta_{0}+\beta_{1} F V O A \_P S_{\mathrm{it}}+\beta_{2} H F T A \_P S_{\mathrm{it}}+\beta_{3} A F S \_P S_{\mathrm{it}}+\beta_{4} O A \_P S_{\mathrm{it}}+\beta_{5} F V O L \_P S_{\mathrm{it}}+ \\
& \beta_{6} H F T L \_P S_{\mathrm{it}}+\beta_{7} O L \_P S_{\mathrm{it}}+\beta_{8} N I \_P S_{\mathrm{it}}+\beta_{9} H i g h \_I n f o+\beta_{10} F V O A \_P S_{\mathrm{it}} * H i g h \_I n f o+ \\
& \beta_{11} H F T A \_P S_{\mathrm{it}}{ }^{*} H i g h \_I n f o+\beta_{12} A F S \_P S_{\mathrm{it}}{ }^{*} H i g h \_I n f o+Y e a r_{t}+C o u n t r y+\varepsilon_{\mathrm{it}}
\end{aligned}
$$

To test the role of institutional investors on the value relevance of fair values, we define an indicator variable INST that equals 1 if the percentage of shares held by institutional shareholders is above the sample median, and 0 otherwise. We amend Equation (2) by including interaction terms between the indicator variable INST and FVOA_PS, HFTA_PS, and AFS_PS.

To proxy for experience with fair values, we exploit differences in institutional investor holdings across countries. We posit that in Nordic countries (i.e., Denmark, Norway, and Sweden), institutional shareholders' experience with the FVO is relatively high, because they

14 Following the design of Song et al. (2010), we interact High_Info only with the variables of interest (i.e., FVOA_PS, HFTA_PS, and AFS_PS) to mitigate multicollinearity issues.

15 Prior literature finds that these variables are associated with stronger information environments (e.g., Leuz and Verrecchia, 2000; Maffett, 2012). 
applied fair value to a substantial portion of financial assets long before IFRS adoption (Bernard et al. 1995; Gjerde et al. 2011). Consistent with this argument, our descriptive statistics (see Table 2) show that the use of the FVO is substantially higher in these countries than the sample mean. INST_Nordic equals 1 if the percentage of Nordic institutional shareholders is above the sample median, and 0 otherwise. To the extent that the level of experience with fair values (at least partially) explains the differences in value relevance across fair value categories and institutional environments, we expect positive interaction terms, particularly for the FVO in bank-based economies.

\section{Sample and data}

\subsection{Sample selection}

We focus on the banking sector because the balance sheets of banks consist primarily of financial instruments. Using the database Thomson Reuters, we identify 355 international bank holding companies applying IFRS. We exclude 33 banks with a reporting date other than December 31, yielding a sample of 322 IFRS banks before data collection.

\section{[Table 1 here]}

Using this sample, we collect data from 2006 to 2009. As the FVO (in its revised, internationally comparable version) is applicable for annual periods on or after January 1, 2006, the earliest FVO data is available as of December 31, 2006. We hand-collect all balance sheetrelated variables and footnote disclosures. The sample is further reduced by 86 observations for which annual reports in English, Danish, French, German, or Italian, are not available. We also 
exclude six banks (24 observations) that do not disclose sufficient information on fair values. ${ }^{16}$ Next, we use Thomson Reuters to gather data on market capitalization, number of outstanding shares, and net income. This data is not available for 137 observations. ${ }^{17}$ We drop 92 observations for which we cannot construct Financial_Structure because of missing data from the World Bank. To avoid bias from extreme outliers (e.g., Belsley et al. 1980; Fox 1991), we drop 42 observations that have absolute values of studentized residuals greater than 2 (Landsman et al. 2008; Song et al. 2010). The final sample consists of 907 bank-years from 46 countries worldwide. $^{18}$

\subsection{Descriptive statistics}

Table 2 shows the extent to which international banks use fair values. While the average proportion of assets (liabilities) measured at fair value to total assets of $17.1 \%(5.9 \%)$ is relatively low, it varies substantially across countries. The proportion of fair valued assets is highest in Belgium, France, and Sweden (more than 38\%) and lowest in Macedonia, Oman, and Romania (less than 3 percent).

\section{[Table 2 here]}

16 These banks do typically not distinguish between FVO and HFT assets despite the requirements of IFRS 7 (IASB 2007, para. 8).

17 Data on institutional shareholders are from SNL Financial. Because of missing data on the percentage of shares held by institutional investors in SNL Financial, the sample is reduced to 688 observations in that analysis.

18 To reduce heterogeneity in institutional factors (e.g., legal environment, political order, and culture), we conduct additional tests for a subsample of European banks (627 observations) for which heterogeneity between countries is likely smaller than in the worldwide sample. The findings from the European subsample confirm our main inferences. 
The application of the FVO also varies substantially across countries. Out of 46 countries, $12(26.1 \%)$ and $19(41.3 \%)$ countries do not use the FVO for financial assets (financial liabilities). Overall, the relatively low ratios of fair values indicate that, even for the banking industry, the measurement attribute "fair value" is less important than alternative measurement concepts such as amortized cost.

\section{[Table 3 here]}

Table 3 shows mean values on selected institutional and firm characteristics for each sample country. Most countries correspond to their a priori perception as market- or bank-based. For example, Australia, Hong Kong, and the United Kingdom have market-based economies, whereas Austria and Germany have bank-based economies. However, some of the classifications appear less intuitive. For example, France, Italy, and Spain are classified as market-based economies. $^{19}$

\subsection{Validity of the institutional proxy}

Panel A of Table 4 reports the mean values of selected institutional variables across the two financial systems. By construction, market-based economies exhibit larger and more liquid stock markets, as indicated by Market_Capitalization and Value_Traded, respectively. Banks in

19 For comparison, in Beck and Levine (2002), the variable Structure_Aggregate indicates that these countries are bank-based. Although Beck and Levine (2002) also use data from the World Bank, they calculate Structure_Aggregate by using data averaged from 1980 to 1989, whereas our reference period is from 1995 to 2004. The change in classification of France, Italy, and Spain suggests that these countries have experienced a larger growth in their stock markets relative to their banking system over the past two decades. 
market-based economies also have more analysts following (\#Analysts) and more dispersed ownership (Share_Float). The regulatory quality index (Reg_Qual) by Kaufmann et al. (2009) is lower in bank-based economies. Moreover, market-based economies have significantly higher disclosure standards (Disclosure) according to the disclosure index from La Porta et al. (2006). The significant differences in both the number of newspapers per 1,000 people (News) and the percentage of households with television (TV\%) (source: World Development Indicators 2012) suggest that our institutional clustering also captures differences in economy-wide information dissemination (Bushman et al. 2004). Finally, the mean percentage of shares held by (Nordic) institutional shareholders of $16.6 \%(2.7 \%)$ in market-based economies is larger than that of $13.8 \%(0.5 \%)$ in bank-based economies, indicating a higher level of investor sophistication (fair value experience) in market-based economies. These univariate comparisons indicate that Financial_Structure is an appropriate aggregate proxy that measures international differences in institutional factors, such as information environment and investor sophistication that we predict to affect investors' ability to process fair value information.

\section{[Table 4 here]}

Panel B of Table 4 reports mean and median values for the extent of fair value measurement relative to total assets partitioned by Financial_Structure. The mean (median) percentage of financial assets measured at fair value to total assets is higher in market-based economies, with $18.6 \%(14.5 \%)$, than in bank-based economies, with $14.4 \%(9.3 \%)$. In particular, the use of the FVO for financial assets differs substantially across institutional environments, as indicated by the mean values of $4.0 \%$ and $1.6 \%$ for market- and bank-based economies, respectively. 
However, while statistically significant, the difference in medians is only $0.3 \%$. The (untabulated) proportion of banks electing the FVO for assets (liabilities) is also significantly higher in market-based economies, with $58.3 \%$ (36.1\%), than in bank-based economies, with $42.6 \%(23.8 \%)$

\section{Empirical results}

\subsection{Value relevance of fair values across institutional environments}

Table 5 shows the OLS regression results of share price on reported fair values for the full sample and the subsamples of market- and bank-based economies. For the full sample, the coefficients $H F T A \_P S$ and $A F S \_P S$ of 0.964 and 0.826 , respectively, are highly significant (tstat $=7.69$ and 7.14 , respectively) and not significantly different from the theoretical value of 1 (F-stat $=0.03$ and 2.27, respectively). Therefore, international investors perceive HFT and AFS

assets as value relevant. ${ }^{20}$ In contrast, the coefficient $F V O \_P S$ of 0.709 is significantly lower than $1($ F-stat $=6.60)$. In addition, the coefficient comparison between $F V O \_P S$ and HFT_PS $\left(A F S \_P S\right)$ reveals that the value relevance of FVO assets is lower than that of HFT (AFS) assets, as indicated by the F-stat of 18.77 (7.66).

\section{[Table 5 here]}

20 Because of the short holding period for HFT assets, fair values are likely close to their amortized cost. In addition, unrealized gains and losses are likely offset by internally hedged positions in the trading portfolio. Thus our interpretation of these findings relies on the assumption that fair values of HFT assets differ from their amortized cost. Given our sample period, which includes the 2008 financial crisis, this assumption appears valid. 
When distinguishing between market-based and bank-based economies, we find that the valuation discount on FVO assets is particularly pronounced in bank-based economies. The value relevance of FVO assets is substantially lower in bank-based than in market-based economies. First, in bank-based economies, the coefficient FVOA_PS of 0.249 is not significantly different from $0(t-s t a t=0.92)$. Second, the (untabulated) cross-equation difference in FVO coefficients is significantly different across market- and bank-based economies (chisquare stat $=4.82 ;$ p-value $=0.03){ }^{21}$ Third, in bank-based economies, FVO assets are substantially less value relevant than HFT $($ F-stat $=27.69)$ and AFS $(F-s t a t=12.99)$ assets. $^{22}$

In contrast, HFT and AFS assets are similarly value relevant, regardless of the institutional environment. The coefficients $H F T A \_P S$ and $A F S \_P S$ are not significantly different from their theoretical value of 1 in both market- and bank-based economies, although the coefficient $A F S \_P S$ of 0.652 (t-stat $\left.=2.32\right)$ in bank-based economies is relatively low. As HFT and AFS assets are also value relevant in bank-based economies, the finding for FVO assets is not merely attributable to a generally lower valuation of accounting fundamentals in such economies.

We are concerned that, due to fewer observations, the lower valuation coefficient for FVO assets in bank-based economies is driven by low statistical power. ${ }^{23}$ We rerun our analysis (untabulated) with the pooled sample and include interaction terms between the fair value

21 We test for differences in coefficients across subsamples with seemingly unrelated regressions using Wald Chisquare tests.

22 Consistent with our findings for FVO assets, the value relevance of FVO liabilities $\left(F V O L \_P S=-0.620\right)$ is lower than that of HFT liabilities $\left(H F T L \_P S=-1.079\right)$ in bank-based economies $(\mathrm{F}$-stat $=14.90)$ but not in marketbased economies $(\mathrm{F}$-stat $=0.34)$.

23 Another concern is that relatively few banks have non-zero FVO assets, i.e., $58.3 \%$ and $42.6 \%$ in market- and bank-based economies, respectively. To test whether our inferences are driven by different proportions of banks applying the FVO, we exclude banks with zero FVO assets. The results are consistent with our main findings. While FVO assets are less value relevant in bank-based economies (coefficient $=0.260$, $\mathrm{t}$-stat $=0.89$ ) than market-based economies (coefficient $=0.863$, t-stat $=9.53$ ), HFT and AFS assets are value relevant in both institutional environments. 
categories and Financial_Structure-which takes the value of 1 for market-based economies, and 0 otherwise. The coefficient FVOA_PS of 0.555 in bank-based economies is both larger in magnitude and more significant $(\mathrm{t}$-stat $=3.83)$ than that in Table 5. The coefficient on the interaction term between the FVO and market-based economies is positive (0.179) and statistically significant $(\mathrm{t}-\mathrm{stat}=2.06) .{ }^{24}$ The coefficients on the interactions with HFT and AFS assets are insignificant, indicating that the value relevance of HFT and AFS assets is similar in both institutional environments. In sum, while these results indicate that the findings in Table 5 might suffer from low statistical power, they also confirm that the value relevance of FVO assets is significantly lower in bank-based economies.

\subsection{Firm-level information environment}

The results in Table 6 show that the value relevance of FVO assets generally improves with higher firm-level information environment. For the full sample, the coefficient on the interaction term FVOA_PS*High_Info is 0.107 and statistically significant $(\mathrm{t}$-stat $=1.72)$. Table 6 further indicates that banks from bank-based economies benefit more from better firm-level information environment $\left(F V O A \_P S^{*} H i g h \_I n f o=0.459 ; \mathrm{t}\right.$-stat $\left.=1.84\right)$ than those from market-based economies $\left(F V O A \_P S * H i g h \_I n f o=0.077 ; \mathrm{t}\right.$-stat $\left.=1.51\right)$, although the cross-equation difference is only marginally significant $($ chi-square stat $=2.55 ; \mathrm{p}$-value $=0.11)$.

24 In addition, the untabulated interaction term between FVOL_PS and market-based economies of $-0.242(\mathrm{t}$-stat $=$ $2.15)$ and the stand-alone coefficient of $-0.691(\mathrm{t}-\mathrm{stat}=-5.71)$ indicate a higher value relevance of FVO liabilities in market-based economies. 


\section{[Table 6 here]}

For all fair value classifications, $F$-tests reveal that the sums of stand-alone coefficients and interaction terms (e.g., FVOA_PS +FVOA_PS*High_Info) are not significantly different from 1 . Therefore, in a strong firm-specific information environment, fair values are value relevant regardless of categorization or institutional environment. ${ }^{25}$ Moreover, the results suggest that the lower value relevance of FVO assets in bank-based economies might be partially explained by a weaker country-level information environment, in turn limiting investors' ability to properly process reported fair values of FVO assets.

\subsection{Institutional investors}

The regression results in Column A of Table 7 show that none of the interaction terms between above median institutional ownership INST and the fair value asset categories are significantly different from 0 . Therefore, the mere presence of institutional investors might not be sufficient for FVO assets to be value relevant in bank-based economies. This finding suggests that even sophisticated investors might lack experience with the FVO.

\section{[Table 7 here]}

25 Because the proxy for firm-level information environment is positively correlated with firm size, we test whether our inferences are driven by differences in bank size. Following Song et al. (2010), we distinguish between large and small banks. We define banks as large (small) if the total assets denominated in USD are above (below) the sample median. For all samples, we find no significant differences between the valuation coefficients (not reported) for large and small banks. Specifically, FVO assets are substantially less value relevant in bank-based economies, consistent with our main findings. In addition, inferences remain when using interaction terms between above median size and fair value categories. 
Column B of Table 7 reveals that the interaction term between INST_Nordic and FVOA_PS of 0.624 is significantly positive $(\mathrm{t}$-stat $=2.29)$ in bank-based economies. This result is consistent with institutional investors from Nordic countries having more experience with fair values, resulting in a higher value relevance of FVO assets in bank-based economies. ${ }^{26}$

Taken together, the results on the effect of institutional shareholders on the value relevance of fair values confirm our main findings that FVO assets are less value relevant in bank-based economies. In addition, the findings lend some support to the interpretation that lack of experience with fair values partly explains the discount of the FVO in bank-based economies.

\section{Further analyses and robustness checks}

\subsection{The role of fair value measurement inputs}

Our dichotomous classification of countries as market- and bank-based may not only tackle differences in information environment and fair value experience, but also capture differences in enforcement and the quality of legal institutions. To mitigate the concern that our findings might be attributable to systematically higher measurement error (or bias) of FVO assets in bank-based economies, we first test whether valuation inputs (i.e., Levels 1, 2, and 3) differ across fair value categories and institutional environments. Second, we rerun regression Equation (1) holding fair value measurement constant. We focus on Level 1 inputs because measurement error is

26 Somewhat unexpected are the negative interaction terms HFTA_PS*INST_Nordic and AFS_PS*INST_Nordic in the full sample and the market-based subsample, respectively. However, the joint coefficients HFTA_PS + HFTA_PS*INST_Nordic and AFS_PS + AFS_PS*INST_Nordic are not significantly different from 1 (F-stat = 0.32 and 0.96 , respectively). 
presumably lowest for fair values that are marked-to-market (Song et al. 2010, Goh et al. $2015)^{27}$

\section{[Table 8 here]}

Panel A of Table 8 shows mean and median proportions of Level 1, 2, and 3 fair value measurement inputs across fair value categories and institutional environments. ${ }^{28}$ The univariate comparisons do not indicate that FVO assets are measured based on systematically lower quality inputs than HFT and AFS assets. On one hand, the mean proportion of Level 3 inputs for FVO assets of $8.7 \%$ is higher (lower) than the mean for HFT (AFS) assets of 3.5\% (14.5\%) percent. On the other hand, the mean proportion of Level 1 inputs for FVO assets of $45.9 \%$ is also higher (lower) than the mean for HFT (AFS) assets of 35.0\% (59.7\%).

Importantly, the proportion of Level 3 inputs for FVO assets is not higher in bank-based $($ mean $=6.5 \%$, median $=0.0 \%)$ than in market-based economies $($ mean $=10.0 \%$, median $=$ $0.5 \%)$. However, the proportion of Level 2 inputs is significantly higher in bank-based (mean $=$ $52.6 \%$, median $=48.0 \%)$ than in market-based economies $($ mean $=41.3 \%$, median $=37.0 \%)$. To

27 Our tests implicitly assume that the definition of Level 1 does not systematically vary across institutions. For example, if the definition of "active market" is less strict in bank-based than in market-based economies, Level 1 fair values in bank-based economies contain generally more measurement error. However, because Level 1d is defined as unadjusted market prices, measurement error or bias should be minimal. We also run robustness analyses focusing on asset types for which the definition is unlikely to vary across institutions (e.g., debt securities vs. equity securities). Inferences from the asset type regressions confirm our findings.

28

The sample size in Panel A is substantially reduced to 140 observations because (a) disclosure of the valuation hierarchy is required only for periods beginning on or after January 1, 2009 (IASB 2009, para. 44G); (b) even under the revised IFRS 7, disclosure of valuation inputs across IAS 39 categories is not mandatory; and (c) to compare fair value measurement inputs across categories, we require observations to have non-zero HFT, AFS, and FVO assets. The sample size in Panel B of Table 8 is larger, as we do not apply restriction (c) to the value relevance tests. 
the extent that investors discount Level 2 fair values (e.g., Goh et al. 2015), this univariate finding might partly explain the valuation discount on FVO assets in bank-based economies.

The multivariate results in Panel B of Table 8 are largely consistent with our main findings. Specifically, while the coefficient $L 1 \_F V O \_P S$ of 0.722 is significant $(\mathrm{t}$-stat $=6.22)$ in marketbased economies, the coefficient $L 1 \_F V O \_P S$ of 0.498 is only marginally significant $(\mathrm{t}-\mathrm{stat}=$ 1.60) in bank-based economies. Moreover, in bank-based economies, the value relevance of Level 1 FVO assets is lower than that of Level 1 HFT and AFS assets (F-stat $=6.75$ and 8.43, respectively). However, the cross-equation difference in FVO coefficients is not statistically significant (chi-square stat $=0.63 ; \mathrm{p}$-value $=0.43$ ), possibly due to low statistical power. Therefore, we additionally conduct pooled sample regressions using interaction terms. The untabulated interaction term between $L 1 \_F V O \_P S$ and Financial_Structure (equal to 1 for market-based economies) of 0.519 is positive and statistically significant $(\mathrm{t}$-stat $=2.43$ ), indicating that FVO assets are more value relevant in market-based than in bank-based economies, despite fair values being marked-to-market.

Taken together, the descriptive and multivariate results both suggest that differences in fair value measurement contribute to variation in the value relevance of fair values, but these findings do not entirely explain the lower value relevance of FVO assets in bank-based economies.

\subsection{The quality of fair values}

Next, we test whether the quality of reported fair values of FVO assets differs between the two institutional regimes. We refer to fair value quality as the ability of fair values to reflect the cash flow and risk characteristics of the underlying assets. Specifically, both the U.S. GAAP and 
the IFRS framework define an accounting amount as relevant if it helps investors to assess the amounts, timing, and uncertainty of future cash flows. To test the ability of fair values to reflect the cash flow and risk characteristics of the underlying FVO assets, we follow Altamuro and Zhang (2013) and estimate the following regression:

$F V O \_T A_{i t}=\beta_{0}+\beta_{1} F V O \_I N C_{i t}+\beta_{2}$ Persistent $_{i}+\beta_{3} F V O \_I N C_{i t} *$ Persistent $_{i}+\beta_{4}$ Size $_{i t}+\varepsilon_{i t}$

FVO_TA is FVO assets scaled by total assets. FVO_INC is the sum of interest income, dividend income, and disposal gains or losses of FVO assets, scaled by total assets. Persistent equals 1 for banks with the highest FVO income persistence, measured as the highest quartile rank of the estimated $\beta_{1}$ coefficient from the regression $F V O \_I N C_{i t+1}=\beta_{0}+\beta_{1} F V O \_I N C_{i t}+$ $\beta_{2}$ Size $_{i t}+\varepsilon_{i t}$, and 0 otherwise. Persistent serves as a summary measure of the risk characteristics of the income associated with the FVO portfolio. Size is the natural logarithm of total assets.

As fair values reflect the present value of future expected cash flows, $\beta_{1}$ in Equation 3 measures the valuation multiple of the income from FVO assets. Moreover, if the measurement of fair values is high quality, fair values should reflect the risk characteristics, i.e., the variation in the persistence of underlying cash flows. Thus we expect banks with more persistent FVO income (i.e., Persistent $=1$ ) to have higher valuation multiples (i.e., $\beta_{3}>0$ ). We estimate Equation (3) separately for market- and bank-based economies, and test whether the coefficient $\beta_{3}$ is positive and different across the two subsamples.

[Table 9 here] 
Table 9 shows that fair value multiples are higher for more persistent FVO income in both market- and bank-based regimes, as suggested by the significantly positive $\beta_{3}$ coefficient. The cross-equation difference between the market- and bank-based $\beta_{3}$ coefficient is not statistically significant $($ chi-square stat $=0.33 ; \mathrm{p}$ value $=0.57) .{ }^{29}$ Therefore, the ability of FVO fair values to reflect the persistence or riskiness of underlying cash flows does not appear to differ between market- and bank-based economies, mitigating the concern that our primary findings are driven by the lower quality of FVO fair values in bank-based economies.

\subsection{Asset type composition}

In addition to our tests on the role of fair value measurement inputs, we investigate whether and how different asset type composition across classification categories affects our findings. We hand-collect data on different asset types (i.e., debt securities, equity securities, hybrid financial instruments, loans and receivables, and investment funds) by fair value categories. Untabulated descriptive statistics reveal that debt securities represent the largest proportion of fair valued assets, with mean (median) proportions for FVO, HFT, and AFS of 52.6\% (51.8\%), 33.4\% (29.3\%), and $67.4 \%(85.5 \%)$, respectively.

We rerun our primary multivariate analysis by holding the asset type (i.e., debt securities) constant. ${ }^{30}$ Untabulated findings show that the coefficient on FVO debt securities is insignificant

29 However, this test might lack statistical power. We also run a pooled regression with a three-way interaction term between FVO_INC, Persistent, and Bank_Based to examine whether the ability of fair values to reflect the persistence of underlying cash flows is different across institutional regimes. Our untabulated results show that this interaction term is positive, but statistically insignificant. In addition, untabulated findings do not indicate a statistical difference in the persistence of income from FVO assets between market- and bank-based economies.

30 Because we also find that FVO assets contain relatively more loans (15.6\% and $7.7 \%$ for market-based and bank-based economies, respectively) than HFT or AFS assets, we test whether our inferences are driven by investors perceiving fair valued loans as less value relevant. We interact FVOA_PS with a dummy variable 
only in bank-based economies, while all other coefficients are statistically significant. However, as in the additional tests holding measurement input constant, the coefficient of 0.572 for the FVO in bank-based environments is larger and slightly more significant $(\mathrm{t}$-stat $=1.39)$ than that from the main tests in Table 5. These results indicate that differences in asset type might explain some but not all of the lower value relevance of FVO assets in bank-based economies.

\subsection{The influence of the 2008 Financial Crisis}

As the 2008 financial crisis falls within our sample period, we test whether solvency or liquidity issues affect our findings. First, banks with low regulatory capital ratios are more likely to engage in fire sales of assets to which investors might apply a valuation discount (Laux and Leuz 2010). Therefore, we test whether our inferences are confounded by low-capitalized banks. ${ }^{31}$ The (untabulated) results are largely consistent with the main findings. In particular, low capitalization has no significant effect on the value relevance of FVO assets, which is lower in bank-based economies.

Second, we examine whether our findings are confounded by banks' different exposure to crisis-sensitive investments. Therefore, we include a binary variable Crisis equal to 1 if a bank

LOAN that equals 1 if the bank applies the FVO to loans (among other asset classes), and 0 otherwise. Untabulated results show that, in market-based economies, the interaction term is significantly negative, indicating that investors perceive FVO assets as less value relevant if also applied to loans. However, in bankbased economies, the coefficient on the interaction term is insignificant, and thus our main inferences are not driven by fair valued loans.

31 We define a bank as low capitalized when the difference between total regulatory capital ratio (BCBS 2006b) and the minimum capital requirement of the bank's country of domicile is below the 25 th percentile (i.e., $2.2 \%$ ). Inferences do not change when we alternatively define banks as low capitalized when the difference between the regulatory capital ratio and the minimum capital requirements is below the 10th percentile (i.e., $1.1 \%$ ). 
has crisis-sensitive investments, and 0 otherwise. ${ }^{32}$ Across all subsamples, the untabulated interaction terms between $H F T A \_P S * C r i s i s$ are significantly negative, indicating that investors apply a discount to trading assets of banks with exposure to crisis-sensitive assets. In bank-based economies, the coefficient for the interaction term FVOA_PS*Crisis of 0.406 is significantly positive $(\mathrm{t}$-stat $=2.56)$. The stand-alone coefficient of 0.230 remains insignificant. A possible interpretation of this result is that banks disclosing their exposure also have a stronger information environment. Importantly, the results do not indicate that the lower value relevance of FVO assets in bank-based economies is driven by different exposure to crisis-sensitive assets.

\section{Conclusions}

Using a global sample of IFRS banks, we investigate whether the value relevance of the fair value categories under IAS 39 (i.e., HFT, FVO, and AFS) varies across institutional environments. We find that FVO assets are generally less value relevant than HFT and AFS assets. This differential value relevance is particularly pronounced in bank-based economies. A richer firm-level information environment and the presence of Nordic institutional investors with fair value experience significantly improve the value relevance of FVO assets in bank-based economies. Therefore, we attribute our findings to institutional frictions (i.e., weak information environment and little experience with fair values) limiting investors' ability to properly process fair value information.

We run several additional analyses to exclude the alternative explanations that differences in value relevance are driven merely by differences in fair value measurement inputs or fair value

32 We define mortgage-backed securities, Alt-A investments, collateralized debt obligations, and leveraged finance products as crisis-sensitive investments (see, e.g., Financial Stability Forum 2008). 
quality. Our tests-holding fair value measurement or asset type constant-confirm our main finding that FVO assets are less value relevant than HFT and AFS assets in bank-based economies. In addition, we find no evidence that the ability of fair values to reflect the persistence of underlying cash flows differs across market- and bank-based economies.

We acknowledge that the paper is limited by its sample size, particularly given the multicollinearity inherent in empirical value relevance models, the relatively low frequency with which banks' choose the FVO for financial assets, and the loss of observations in some of the additional analyses. Moreover, as the sample period closely overlaps with the 2008 financial crisis, the findings might not generalize to other periods.

Despite these limitations, our study extends the literature by providing evidence that factors other than fair value measurement issues play a significant role in determining value relevance of fair values. Our findings suggest that international variation in investors' ability to process fair value information impacts the value relevance of fair values. 


\section{References}

Ahmed, A. S., E. Kilic, and G. J. Lobo. 2006. Does recognition versus disclosure matter? Evidence from value-relevance of banks' recognized and disclosed derivative financial instruments. The Accounting Review 81 (3): 567-588.

Ali, A., and L-S. Hwang. 2000. Country-specific factors related to financial reporting and the value relevance of accounting data. Journal of Accounting Research 38 (1): 1-21.

Altamuro, J., and H. Zhang. 2013. The financial reporting of fair value based on managerial inputs versus market inputs: evidence from mortgage servicing rights. Review of Accounting Studies 18: 833-858.

Ball, R., X. Li, and L. Shivakumar. 2015. Contractibility and Transparency of Financial Statement Information Prepared Under IFRS: Evidence from Debt Contracts Around IFRS Adoption. Journal of Accounting Resesarch 53 (5): 915-963.

S. P. Kothari, and A. Robin. 2000. The effect of international institutional factors on properties of accounting earnings. Journal of Accounting and Economics 29 (1): 1-51.

Balsam S., E. Bartov, and C. Marquardt. 2000. Accruals Management, Investor Sophistication, and Equity Valuation: Evidence from 10-Q Filings. Journal of Accounting Resesarch 40 (4): 987-1012.

Barth, M. E. 1994. Fair value accounting: Evidence from investment securities and the market valuation of banks. The Accounting Review 69 (1): 1-25.

- W. H. Beaver, and W. R. Landsman. 1996. Value-relevance of banks' fair value disclosures under FAS No. 107. The Accounting Review 71 (4): 513-537.

W. H. Beaver, and W. R. Landsman. 2001. The relevance of the value relevance literature for accounting standardsetting: Another view. Journal of Accounting and Economics 31 (1-3): 77-104.

- and G. Clinch. 2009. Scale effects in capital markets-based accounting research. Journal of Business Finance \& Accounting 36 (3-4): 253-288.

- W. R. Landsman, D. Young, and Z. Zhuang. 2014. Relevance of differences between net income based on IFRS and domestic standards for European firms. Journal of Business Finance and Accounting 43(3): 297-327.

Bartov, E., S. Radhakrishnan, and I. Krinsky. 2000. Investor Sophistication and Patterns in Stock Returns After Earnings Announcements. The Accounting Review 75 (1): $43-63$. 
Basel Committee on Banking Supervision (BCBS). 2006a. Supervisory guidance on the use of the fair value option for financial instruments by banks, June 2006.

- 2006b. Basel II: International convergence of capital measurement and capital standards: A revised framework, Comprehensive version, June 2006.

Beck, T., and R. Levine. 2002. Industry growth and capital allocation: Does having a market- or bank-based system matter? Journal of Financial Economics 64: 147-180.

Belsley, D. A., E. Kuh, and R. E. Welsch. 1980. Regression Diagnostics: Identifying Influential Data and Sources of Collinearity. New York: John Wiley \& Sons, Inc.

Bernard, V. and K. Schipper (1994). Recognition and Disclosure in Financial Reporting. Working Paper, University of Michigan and University of Chicago.

Bernard, V. L., R. C. Merton, and K. C. Palepu. 1995. Mark-to-market accounting for banks and thrifts: Lessons from the Danish experience. Journal of Accounting Research 33 (1): 1-32.

Bischof, J. 2009. The effect of IFRS 7 adoption on bank disclosure in Europe. Accounting in Europe 6 (1-2): 167-194.

H. Daske, and C. Sextroh. 2014. Fair value-related information in analysts' decision processes: evidence from the Financial Crisis. Journal of Business Finance and Accounting 41(3): 363-400.

Bushman, R. M., Piotroski, and A. J. Smith. 2004. What determines corporate transparency? Journal of Accounting Research 42 (2): 207-252.

Chambers, D., T. J. Linsmeier, C. Shakespeare, and T. Sougiannis. 2007. An evaluation of SFAS No. 130 comprehensive disclosures. Review of Accounting Studies 12 (4): 557-593.

Chang, Y-L., C-C. Liu, and S. G. Ryan. 2011. Why banks' elected SFAS 159's fair value option: Opportunism versus compliance with the standard's intent. Working Paper, National Taiwan University.

Collins, D. W., G. Gong, and P. Hribar. 2003. Investor sophistication and the mispricing of accruals. Review of Accounting Studies 8 (2-3): 251-276.

DeFond, M. L., M. Hung, S. Li, and Y. Li. 2015. Does mandatory IFRS adoption affect crash risk? The Accounting Review 90 (1): 265-299.

De George, E. T., X. Li, and L. Shivakumar. 2016. A review of the IFRS adoption literature. Review of Accounting Studies (forthcoming). 
Dong, M., S. Ryan, and X-J. Zhang. 2014. Preserving amortized costs within a fair-value accounting framework: reclassification of gains and losses on available-for-sale securities upon realization. Review of Accounting Studies, Vol. 19, Issue 1, pp. 240-282.

Eccher, E. A., K. Ramesh, and S. R. Thiagarajan. 1996. Fair value disclosures by bank holding companies. Journal of Accounting and Economics 22 (1-3): 79-117.

European Central Bank (ECB). 2004. Fair value accounting and financial stability. Occasional Paper Series (13): 3-48.

European Securities and Markets Authority (ESMA). 2010. Activity Report on IFRS Enforcement in 2010.

Evans, M. E., L. Hodder, P. E. Hopkins. 2014. The predictive ability of fair values for future financial performance of commercial banks and the relation of predictive ability to banks' share price. Contemporary Accounting Research 31 (1): 13-44.

Financial Accounting Standards Board (FASB). 1993. Accounting for Certain Investments in Debt and Equity Securities, Statement of Financial Accounting Standards No. 115, Norwalk, CT: FASB.

Financial Accounting Standards Board (FASB). 2007. Fair Value Option for Financial Assets and Financial Liabilities, Statement of Financial Accounting Standards No. 159. Norwalk, CT: FASB.

Fiechter, P. 2011. The effects of the fair value option under IAS 39 on the volatility of bank earnings. Journal of International Accounting Research, 10 (1): 85-108.

Financial Stability Forum. 2008. Report of the Financial Stability Forum on enhancing market and institutional resilience, April 2008.

Fox, J. 1991. Regression Diagnostics. Newbury Park, CA: Sage.

Gjerde, O., K. Knivsla, and F. Saettem. 2011. The value relevance of financial reporting in Norway 1965-2004. Scandinavian Journal of Management, 27 (1): 113-128.

Goh, B., D. Li, J. Ng, and K. Yong. 2015. Market pricing of banks' fair value assets reported under SFAS 157 since the 2008 financial crisis. Journal of Accounting and Public Policy, 34 (2): 129-145.

International Accounting Standards Board (IASB). 2006. Financial Instruments: Recognition and Measurement. International Accounting Standard 39. London, U.K.: IASB.

\footnotetext{
London, U.K.: IASB.
} 
2009. Improving Disclosures about Financial Instruments: Amendment to IFRS 7. London, U.K.: IASB.

. 2011. Financial Instruments. International Financial Reporting Standard 9. London, U.K.: IASB.

Kaufmann, D., A. Kraay, and M. Mastruzzi. 2009. Governance matters VIII: Aggregate and individual governance indicators 1996-2008. Policy research working paper, The World Bank.

Kolev, K. 2009. Do investors perceive marking-to-model as marking-to-myth? Early evidence from FAS 157 disclosure. Working paper, New York University.

Koonce, L., K. K. Nelson, and C. M. Shakespeare. 2011. Judging the relevance of fair value for financial instruments. The Accounting Review 86 (6): 2075-2098.

La Porta, R., F. Lopez-de-Silanes, and A. Shleifer. 2006. What Works in Securities Laws? Journal of Finance 61 (1): 1-32.

Landsman, W. R., K. V. Peasnell, and C. Shakespeare. 2008. Are asset securitizations sales or loans? The Accounting Review 83 (5): 1251-1272.

Lang, M., K. Lins, and M. Maffett. 2012. Transparency, liquidity, and valuation: International evidence on when transparency matters most. Journal of Accounting Research, 50 (3): 729774.

Laux, C., and C. Leuz. 2010. Did fair-value accounting contribute to the financial crisis? Journal of Economic Perspectives 24 (1): 93-118.

Leuz, C., and R. Verrecchia. 2000. The economic consequences of increased disclosure. Journal of Accounting Research 38 (Supplement): 91-124.

Leuz, C., D. Nanda, and P. Wysocki. 2003. Earnings management and investor protection: An international comparison. Journal of Financial Economics 69 (3): 505-527.

Leuz, C. 2010. Different approaches to corporate reporting regulation: How jurisdictions differ and why? Accounting and Business Research 40 (3): 229-256.

Maffett, M. 2012. Financial reporting opacity and informed trading by international institutional investors. Journal of Accounting and Economics 54 (2-3): 201-220.

Matherat, S. 2008. Fair value accounting and financial stability challenges and dynamics. Banque de France, Financial Stability Review - Valuation and financial stability, No. 12, October 2008. 
Müller, M., E. Riedl, and T. Sellhorn. 2015. Recognition versus disclosure of fair values. The Accounting Review 90 (6): 2411-2447.

Nelson, K. 1996. Fair value accounting for commercial banks: An empirical analysis of FAS No.107. The Accounting Review 71 (2): 161-182.

Park, M. S., T. Park, and B. T. Ro. 1999. Fair value disclosures for investment securities and bank equity: Evidence from SFAs No. 155. Journal of Accounting, Auditing and Finance 14: 347-370.

Petersen, M. 2009. Estimating standard errors in finance panel data sets: Comparing approaches, Review of Financial Studies 22(1): 435-480.

Rogers, W. 1993. Regression standard errors in clustered samples. Stata Technical Bulletin, (13): 19-23.

Ryan, S. G. 1999. Discussion of "Fair Value Disclosures for Investment Securities and Bank Equity: Evidence from SFAS No. 115", Journal of Accounting, Auditing and Finance 14: 371-377.

Schipper, K. 2007. Required Disclosures in Financial Reports. Accounting Review 82(2): 301326.

Skinner. D. J. 1996. Are disclosures about bank derivatives and employee stock options "value relevant"? Journal of Accounting and Economics 22 (2): 393-405.

Song, C. J. 2008. An Evaluation of FAS 159 Fair Value Option: Evidence from the Banking Industry, working paper, Virgina Tech.

Song, C. J., W. B. Thomas, and H. Yi. 2010. Value relevance of FAS 157 fair value hierarchy information and the impact of corporate governance mechanisms, The Accounting Review 85 (4): $1375-1410$. 
TABLE 1

Sample Selection

\begin{tabular}{|c|c|c|c|c|c|c|}
\hline Sample selection process & $\begin{array}{r}\text { \# of Banks } \\
2006\end{array}$ & $\begin{array}{r}\text { \# of Banks } \\
2007\end{array}$ & $\begin{array}{r}\text { \# of Banks } \\
\mathbf{2 0 0 8}\end{array}$ & $\begin{array}{r}\text { \# of Banks } \\
2009\end{array}$ & Total & Percent \\
\hline = Global IFRS bank sample (Thomson Reuters) & 355 & & & & & $100 \%$ \\
\hline I. Reporting date is not as of December 31 & (33) & & & & & \\
\hline$=$ Sample before data collection & 322 & 322 & 322 & 322 & 1288 & $91 \%$ \\
\hline . Annual report is not available & (18) & (18) & $(24)$ & (26) & (86) & \\
\hline . Missing fair value data in annual reports & (6) & (6) & $(6)$ & $(6)$ & (24) & \\
\hline$=$ Sample with available data on fair value & 298 & 298 & 292 & 290 & 1178 & $83 \%$ \\
\hline . Missing data on market capitalization & (39) & (35) & $(30)$ & (33) & $(137)$ & \\
\hline I. Missing data on Financial_Structure & $(23)$ & (23) & $(23)$ & $(23)$ & $(92)$ & \\
\hline I. Studentized residuals greater than $[+/-2]$ & (17) & (13) & (7) & $(5)$ & $(42)$ & \\
\hline$=$ Sample for value relevance tests & 219 & 227 & 232 & 229 & 907 & $64 \%$ \\
\hline \multicolumn{7}{|c|}{$\begin{array}{l}\text { This table outlines the sample selection process. The sample banks are initially identified from Thomson Reuters, resulting in a global sample of } 355 \text { banks } \\
\text { applying IFRS. We exclude } 33 \text { banks with a reporting date other than December } 31 \text {. For } 2006 \text { to } 2009 \text {, we hand-collect data on fair values in the annual } \\
\text { reports. This procedure yields an international sample of } 1,178 \text { bank-years from } 57 \text { countries with available data on fair values. For the value relevance } \\
\text { tests, we use data on market capitalization, number of outstanding shares, and net income from Thomson Reuters. We drop } 137 \text { observations because of } \\
\text { missing data in Thomson Reuters. We drop } 92 \text { observations because of missing data from the World Bank on Financial_Structure. Finally, to avoid bias } \\
\text { from extreme outliers (e.g., Bels ley et al. 1980; Fox 1991; Landsman et al. 2008; Song et al. 2010), we exclude } 42 \text { observations . Our final sample consists of } \\
907 \text { bank-years from } 46 \text { countries. }\end{array}$} \\
\hline
\end{tabular}


TABLE 2

The Use of Fair Values around the World (2006 to 2009)

Country mean fair values as a percentage of total assets or liabilities

Financial Assets at Fair Value

Financial Liabilities at Fair Value

\begin{tabular}{|c|c|c|c|c|c|c|c|c|c|c|}
\hline \multirow[b]{2}{*}{ Country } & & & & & & \multirow[b]{2}{*}{$O A$} & & \multirow[b]{2}{*}{$O L$} \\
\hline & $\mathbf{N}$ & HFTA & FVOA & $A F S$ & Total_FVA & & HFTL & FVOL & Total_FVL & \\
\hline Australia & 4 & $8.09 \%$ & $4.63 \%$ & $0.50 \%$ & $13.2 \%$ & $86.8 \%$ & $4.50 \%$ & $3.59 \%$ & $8.1 \%$ & $91.9 \%$ \\
\hline Austria & 25 & $2.31 \%$ & $2.46 \%$ & $7.21 \%$ & $12.0 \%$ & $88.0 \%$ & $0.58 \%$ & $1.76 \%$ & $2.3 \%$ & $97.7 \%$ \\
\hline Bahrain & 36 & $1.72 \%$ & $1.12 \%$ & $20.26 \%$ & $23.1 \%$ & $76.9 \%$ & $0.22 \%$ & $0.00 \%$ & $0.2 \%$ & $99.8 \%$ \\
\hline Belgium & 11 & $9.89 \%$ & $3.31 \%$ & $27.04 \%$ & $40.2 \%$ & $59.8 \%$ & $7.78 \%$ & $4.57 \%$ & $12.3 \%$ & $87.7 \%$ \\
\hline Botswana & 4 & $1.53 \%$ & $0.00 \%$ & $21.00 \%$ & $22.5 \%$ & $77.5 \%$ & $0.00 \%$ & $0.00 \%$ & $0.0 \%$ & $100.0 \%$ \\
\hline Bulgaria & 11 & $1.19 \%$ & $0.00 \%$ & $3.69 \%$ & $4.9 \%$ & $95.1 \%$ & $0.14 \%$ & $1.22 \%$ & $1.4 \%$ & $98.6 \%$ \\
\hline China & 12 & $0.95 \%$ & $0.30 \%$ & $7.28 \%$ & $8.5 \%$ & $91.5 \%$ & $0.40 \%$ & $0.42 \%$ & $0.8 \%$ & $99.2 \%$ \\
\hline Croatia & 12 & $0.77 \%$ & $0.49 \%$ & $4.71 \%$ & $6.0 \%$ & $94.0 \%$ & $0.18 \%$ & $0.00 \%$ & $0.2 \%$ & $99.8 \%$ \\
\hline Cyprus & 12 & $1.10 \%$ & $0.62 \%$ & $13.18 \%$ & $14.9 \%$ & $85.1 \%$ & $0.30 \%$ & $0.01 \%$ & $0.3 \%$ & $99.7 \%$ \\
\hline Czech Republic & 2 & $6.54 \%$ & $0.00 \%$ & $13.52 \%$ & $20.1 \%$ & $79.9 \%$ & $2.48 \%$ & $0.00 \%$ & $2.5 \%$ & $97.5 \%$ \\
\hline Denmark & 59 & $8.41 \%$ & $11.23 \%$ & $0.26 \%$ & $19.9 \%$ & $80.1 \%$ & $2.30 \%$ & $3.89 \%$ & $6.2 \%$ & $93.8 \%$ \\
\hline Egypt & 8 & $1.02 \%$ & $0.00 \%$ & $7.54 \%$ & $8.6 \%$ & $91.4 \%$ & $0.18 \%$ & $0.00 \%$ & $0.2 \%$ & $99.8 \%$ \\
\hline Finland & 8 & $6.05 \%$ & $5.38 \%$ & $6.73 \%$ & $18.2 \%$ & $81.8 \%$ & $1.77 \%$ & $3.40 \%$ & $5.2 \%$ & $94.8 \%$ \\
\hline France & 19 & $30.61 \%$ & $2.72 \%$ & $6.43 \%$ & $39.8 \%$ & $60.2 \%$ & $24.52 \%$ & $3.32 \%$ & $27.8 \%$ & $72.2 \%$ \\
\hline Germany & 47 & $13.20 \%$ & $5.09 \%$ & $12.00 \%$ & $30.3 \%$ & $69.7 \%$ & $7.55 \%$ & $1.56 \%$ & $9.1 \%$ & $90.9 \%$ \\
\hline Greece & 47 & $3.16 \%$ & $1.20 \%$ & $8.78 \%$ & $13.1 \%$ & $86.9 \%$ & $0.61 \%$ & $0.63 \%$ & $1.2 \%$ & $98.8 \%$ \\
\hline Hong Kong & 4 & $0.53 \%$ & $0.04 \%$ & $6.57 \%$ & $7.1 \%$ & $92.9 \%$ & $0.15 \%$ & $0.03 \%$ & $0.2 \%$ & $99.8 \%$ \\
\hline Hungary & 8 & $1.48 \%$ & $0.00 \%$ & $6.82 \%$ & $8.3 \%$ & $91.7 \%$ & $1.48 \%$ & $8.63 \%$ & $10.1 \%$ & $89.9 \%$ \\
\hline Ireland & 6 & $5.09 \%$ & $1.54 \%$ & $13.34 \%$ & $20.0 \%$ & $80.0 \%$ & $3.03 \%$ & $1.29 \%$ & $4.3 \%$ & $95.7 \%$ \\
\hline Israel & 4 & $3.04 \%$ & $0.00 \%$ & $16.76 \%$ & $19.8 \%$ & $80.2 \%$ & $2.65 \%$ & $0.00 \%$ & $2.6 \%$ & $97.4 \%$ \\
\hline Italy & 102 & $11.38 \%$ & $3.05 \%$ & $6.48 \%$ & $20.9 \%$ & $79.1 \%$ & $3.43 \%$ & $4.19 \%$ & $7.6 \%$ & $92.4 \%$ \\
\hline Jordan & 40 & $1.59 \%$ & $0.04 \%$ & $12.20 \%$ & $13.8 \%$ & $86.2 \%$ & $0.04 \%$ & $0.00 \%$ & $0.0 \%$ & $100.0 \%$ \\
\hline Kazakhstan & 23 & $3.59 \%$ & $0.01 \%$ & $3.01 \%$ & $6.6 \%$ & $93.4 \%$ & $0.36 \%$ & $0.00 \%$ & $0.4 \%$ & $99.6 \%$ \\
\hline Kenya & 24 & $0.87 \%$ & $0.01 \%$ & $6.79 \%$ & $7.7 \%$ & $92.3 \%$ & $0.01 \%$ & $12.49 \%$ & $12.5 \%$ & $87.5 \%$ \\
\hline Kuwait & 34 & $0.17 \%$ & $0.73 \%$ & $5.18 \%$ & $6.1 \%$ & $93.9 \%$ & $0.06 \%$ & $0.00 \%$ & $0.1 \%$ & $99.9 \%$ \\
\hline Latvia & 4 & $0.08 \%$ & $2.37 \%$ & $0.04 \%$ & $2.5 \%$ & $97.5 \%$ & $0.08 \%$ & $0.00 \%$ & $0.1 \%$ & $99.9 \%$ \\
\hline Lithuania & 8 & $2.47 \%$ & $0.39 \%$ & $1.25 \%$ & $4.1 \%$ & $95.9 \%$ & $0.02 \%$ & $0.00 \%$ & $0.0 \%$ & $100.0 \%$ \\
\hline Macedonia & 2 & $0.23 \%$ & $0.00 \%$ & $0.76 \%$ & $1.0 \%$ & $99.0 \%$ & $0.00 \%$ & $0.00 \%$ & $0.0 \%$ & $100.0 \%$ \\
\hline Malaysia & 4 & $4.22 \%$ & $0.00 \%$ & $6.80 \%$ & $11.0 \%$ & $89.0 \%$ & $0.21 \%$ & $0.00 \%$ & $0.2 \%$ & $99.8 \%$ \\
\hline Mauritius & 8 & $0.20 \%$ & $0.00 \%$ & $4.11 \%$ & $4.3 \%$ & $95.7 \%$ & $0.06 \%$ & $0.00 \%$ & $0.1 \%$ & $99.9 \%$ \\
\hline Norway & 39 & $2.84 \%$ & $10.16 \%$ & $1.17 \%$ & $14.0 \%$ & $86.0 \%$ & $3.02 \%$ & $9.89 \%$ & $12.9 \%$ & $87.1 \%$ \\
\hline Oman & 20 & $0.61 \%$ & $0.11 \%$ & $1.92 \%$ & $2.6 \%$ & $97.4 \%$ & $0.47 \%$ & $0.00 \%$ & $0.5 \%$ & $99.5 \%$ \\
\hline Pakistan & 19 & $1.43 \%$ & $0.00 \%$ & $21.60 \%$ & $23.0 \%$ & $77.0 \%$ & $1.25 \%$ & $0.00 \%$ & $1.2 \%$ & $98.8 \%$ \\
\hline Philippines & 4 & $7.52 \%$ & $1.32 \%$ & $18.17 \%$ & $27.0 \%$ & $73.0 \%$ & $1.60 \%$ & $2.29 \%$ & $3.9 \%$ & $96.1 \%$ \\
\hline Poland & 56 & $5.81 \%$ & $2.19 \%$ & $10.09 \%$ & $18.1 \%$ & $81.9 \%$ & $3.22 \%$ & $0.22 \%$ & $3.4 \%$ & $96.6 \%$ \\
\hline Portugal & 12 & $3.77 \%$ & $1.22 \%$ & $5.52 \%$ & $10.5 \%$ & $89.5 \%$ & $1.55 \%$ & $5.92 \%$ & $7.5 \%$ & $92.5 \%$ \\
\hline Romania & 4 & $0.15 \%$ & $0.00 \%$ & $1.70 \%$ & $1.9 \%$ & $98.1 \%$ & $0.31 \%$ & $0.00 \%$ & $0.3 \%$ & $99.7 \%$ \\
\hline Russia & 14 & $4.76 \%$ & $1.54 \%$ & $2.09 \%$ & $8.4 \%$ & $91.6 \%$ & $0.52 \%$ & $0.00 \%$ & $0.5 \%$ & $99.5 \%$ \\
\hline Saudi Arabia & 28 & $1.89 \%$ & $0.41 \%$ & $7.73 \%$ & $10.0 \%$ & $90.0 \%$ & $0.71 \%$ & $0.11 \%$ & $0.8 \%$ & $99.2 \%$ \\
\hline Slovakia & 4 & $4.07 \%$ & $0.00 \%$ & $1.19 \%$ & $5.3 \%$ & $94.7 \%$ & $0.55 \%$ & $0.00 \%$ & $0.6 \%$ & $99.4 \%$ \\
\hline South Africa & 4 & $10.02 \%$ & $11.26 \%$ & $1.08 \%$ & $22.4 \%$ & $77.6 \%$ & $10.50 \%$ & $13.55 \%$ & $24.0 \%$ & $76.0 \%$ \\
\hline Spain & 32 & $6.23 \%$ & $0.94 \%$ & $6.66 \%$ & $13.8 \%$ & $86.2 \%$ & $3.78 \%$ & $0.78 \%$ & $4.6 \%$ & $95.4 \%$ \\
\hline Sweden & 20 & $15.39 \%$ & $20.90 \%$ & $2.06 \%$ & $38.3 \%$ & $61.7 \%$ & $10.22 \%$ & $15.72 \%$ & $25.9 \%$ & $74.1 \%$ \\
\hline Switzerland & 20 & $10.19 \%$ & $6.61 \%$ & $10.16 \%$ & $27.0 \%$ & $73.0 \%$ & $7.49 \%$ & $8.13 \%$ & $15.6 \%$ & $84.4 \%$ \\
\hline Turkey & 8 & $2.05 \%$ & $0.01 \%$ & $12.50 \%$ & $14.6 \%$ & $85.4 \%$ & $0.45 \%$ & $0.00 \%$ & $0.4 \%$ & $99.6 \%$ \\
\hline United Kingdom & 35 & $15.03 \%$ & $2.97 \%$ & $7.29 \%$ & $25.3 \%$ & $74.7 \%$ & $11.78 \%$ & $1.41 \%$ & $13.2 \%$ & $86.8 \%$ \\
\hline Total & 907 & $6.2 \%$ & $3.2 \%$ & $7.7 \%$ & $17.1 \%$ & $82.9 \%$ & $3.2 \%$ & $2.7 \%$ & $5.9 \%$ & $94.1 \%$ \\
\hline
\end{tabular}

This table presents mean values of the percentage of fair value assets (liabilities) relative to total assets (liabilities) by fair value categories for each country in the sample. HFTA $(H F T L)$ are trading assets (liabilities). FVOA (FVOL) are assets (liabilities) under the FVO. AFS are available-for-sale financial assets. Total_FVA (Total_FVL) is the sum of financial assets (liabilities) measured at fair value. $O A(O L)$ are other assets (liabilities). 
TABLE 3

Country-level and Firm-level Institutional Characteristics

\begin{tabular}{|c|c|c|c|c|c|c|c|c|}
\hline \multirow[b]{2}{*}{ Country } & \multirow[b]{2}{*}{$\mathbf{N}$} & \multicolumn{4}{|c|}{ Country-level characteristics } & \multicolumn{3}{|c|}{ Firm-level characteristics } \\
\hline & & $\begin{array}{l}\text { Structure } \\
\text { Aggregate }\end{array}$ & $\begin{array}{l}\text { Financial } \\
\text { Structure }\end{array}$ & Bank_Credit & Value_Traded & $\begin{array}{l}\text { MV } \\
\text { Equity }\end{array}$ & \#Analysts & $\begin{array}{l}\text { Share } \\
\text { Float \% }\end{array}$ \\
\hline Australia & 4 & 0.91 & Market-based & 0.79 & 0.51 & 43104 & 1.00 & 99.05 \\
\hline Austria & 25 & -1.84 & Bank-based & 0.99 & 0.06 & 5055 & 5.00 & 46.37 \\
\hline Bahrain & 36 & 0.55 & Market-based & 0.45 & 0.06 & 1145 & 0.86 & 53.99 \\
\hline Belgium & 11 & -0.10 & Bank-based & 0.74 & 0.14 & 24482 & 22.57 & 79.53 \\
\hline Botswana & 4 & -0.21 & Bank-based & 0.13 & 0.01 & 773 & 3.00 & 99.00 \\
\hline Bulgaria & 11 & -2.20 & Bank-based & 0.20 & 0.01 & 301 & 1.36 & 27.26 \\
\hline China & 12 & -0.74 & Bank-based & 1.00 & 0.30 & 126146 & 38.00 & 33.06 \\
\hline Croatia & 12 & -1.81 & Bank-based & 0.35 & 0.01 & 2241 & 0.00 & 42.59 \\
\hline Cyprus & 12 & -1.45 & Bank-based & 1.44 & 0.22 & 3577 & 12.00 & 84.34 \\
\hline Czech Republic & 2 & -0.52 & Bank-based & 0.50 & 0.09 & 5876 & 21.00 & 38.73 \\
\hline Denmark & 59 & 0.49 & Market-based & 0.82 & 0.32 & 1933 & 3.72 & 85.77 \\
\hline Egypt & 8 & -0.56 & Bank-based & 0.45 & 0.05 & 2133 & 13.50 & 60.90 \\
\hline Finland & 8 & 1.52 & Market-based & 0.56 & 0.79 & 1648 & 5.50 & 75.68 \\
\hline France & 19 & 0.49 & Market-based & 0.85 & 0.49 & 38317 & 25.58 & 50.08 \\
\hline Germany & 47 & -0.24 & Bank-based & 1.12 & 0.43 & 7272 & 9.38 & 31.98 \\
\hline Greece & 47 & 0.77 & Market-based & 0.43 & 0.34 & 4422 & 11.07 & 46.92 \\
\hline Hong Kong & 4 & 1.53 & Market-based & 1.52 & 1.47 & 158314 & 37.00 & 26.79 \\
\hline Hungary & 8 & 0.16 & Market-based & 0.28 & 0.14 & 4686 & 13.50 & 81.21 \\
\hline Ireland & 6 & 0.04 & Bank-based & 0.89 & 0.25 & 8399 & 6.33 & 98.28 \\
\hline Israel & 4 & -0.04 & Bank-based & 0.73 & 0.21 & 1357 & 0.00 & 15.40 \\
\hline Italy & 102 & 0.17 & Market-based & 0.67 & 0.35 & 7914 & 11.64 & 62.55 \\
\hline Jordan & 40 & 0.11 & Market-based & 0.69 & 0.11 & 1567 & 0.56 & 28.49 \\
\hline Kazakhstan & 23 & -1.19 & Bank-based & 0.11 & 0.00 & 1522 & 1.74 & 44.59 \\
\hline Kenya & 24 & -1.20 & Bank-based & 0.24 & 0.01 & 428 & 2.33 & 62.49 \\
\hline Kuwait & 34 & 1.36 & Market-based & 0.46 & 0.49 & 3992 & 3.03 & 80.68 \\
\hline Latvia & 4 & -1.21 & Bank-based & 0.20 & 0.01 & 70 & 0.00 & 82.85 \\
\hline Lithuania & 8 & -0.23 & Bank-based & 0.14 & 0.02 & 152 & 0.00 & 75.73 \\
\hline Macedonia & 2 & -2.83 & Bank-based & 0.21 & 0.01 & 127 & 1.00 & 94.02 \\
\hline Malaysia & 4 & 0.90 & Market-based & 1.26 & 0.75 & 2891 & 22.00 & 75.00 \\
\hline Mauritius & 8 & -1.01 & Bank-based & 0.53 & 0.02 & 821 & 2.00 & 99.50 \\
\hline Norway & 39 & 0.16 & Market-based & 0.65 & 0.27 & 1711 & 6.74 & 90.97 \\
\hline
\end{tabular}


TABLE 3 (continued)

\begin{tabular}{|c|c|c|c|c|c|c|c|c|}
\hline \multirow[b]{2}{*}{ Country } & \multirow[b]{2}{*}{$\mathbf{N}$} & \multicolumn{4}{|c|}{ Country-level characteristics } & \multicolumn{3}{|c|}{ Firm-level characteristics } \\
\hline & & $\begin{array}{l}\text { Structure } \\
\text { Aggregate }\end{array}$ & $\begin{array}{l}\text { Financial } \\
\text { Structure }\end{array}$ & Bank_Credit & Value_Traded & $\begin{array}{l}\text { MV } \\
\text { Equity }\end{array}$ & \#Analysts & $\begin{array}{l}\text { Share } \\
\text { Float \% }\end{array}$ \\
\hline Oman & 20 & -0.54 & Bank-based & 0.36 & 0.04 & 1282 & 7.20 & 62.05 \\
\hline Pakistan & 19 & 0.60 & Market-based & 0.23 & 0.28 & 3365 & 1.42 & 67.61 \\
\hline Philippines & 4 & 0.69 & Market-based & 0.36 & 0.14 & 453 & 6.00 & 83.01 \\
\hline Poland & 56 & -0.39 & Bank-based & 0.23 & 0.05 & 3764 & 12.12 & 31.07 \\
\hline Portugal & 12 & -0.72 & Bank-based & 1.02 & 0.20 & 5400 & 12.50 & 68.97 \\
\hline Romania & 4 & -0.98 & Bank-based & 0.09 & 0.01 & 3932 & 0.00 & 39.72 \\
\hline Russia & 14 & 0.57 & Market-based & 0.13 & 0.06 & 22217 & 9.43 & 51.34 \\
\hline Saudi Arabia & 28 & 1.07 & Market-based & 0.25 & 0.24 & 10496 & 10.43 & 53.10 \\
\hline Slovakia & 4 & -1.94 & Bank-based & 0.42 & 0.03 & 1821 & 0.00 & 77.05 \\
\hline South Africa & 4 & 1.53 & Market-based & 0.62 & 0.43 & 6909 & 11.00 & 99.00 \\
\hline Spain & 32 & 0.68 & Market-based & 0.89 & 0.96 & 26445 & 30.43 & 73.00 \\
\hline Sweden & 20 & 1.78 & Market-based & 0.58 & 0.85 & 14996 & 23.60 & 76.12 \\
\hline Switzerland & 20 & 1.32 & Market-based & 1.54 & 1.71 & 6767 & 11.50 & 43.59 \\
\hline Turkey & 8 & 1.54 & Market-based & 0.14 & 0.28 & 5726 & 14.00 & 64.50 \\
\hline United Kingdom & 35 & 0.99 & Market-based & 1.21 & 0.89 & 39548 & 19.87 & 68.79 \\
\hline Total & 907 & 0.99 & & 1.21 & 0.89 & 10178 & 10.03 & 59.19 \\
\hline
\end{tabular}

This table presents country mean statistics for institutional characteristics. Structure_Aggregate is the first principal component of two variables that measure the comparative activity and size of stock markets relative to banks (Beck and Levine 2002). The first variable, Structure_Activity, equals the log of the ratio of stock value traded (Value_Traded) to bank credit (Bank_Credit). Value_Traded equals the value of stock transactions as a share of GDP. Bank_Credit equals the claims of the banking sector on the private sector as a share of GDP. The second variable, Structure_Size, equals the log of the ratio of stock market capitalization (Market_Capitalization) to Bank_Credit.Market_Capitalization is defined as the value of listed shares divided by GDP, measuring the size of stock markets relative to the economy. We use data averaged over the period 1995-2004 for the construction of Structure_Aggregate (Source: World Bank). Financial_Structure is a dichotomous variable based on Structure_Aggregate. Countries with above (below) median values for Structure_Aggregate are classified as market-based (bank-based) economies. Market value of equity (MV_Equity) is the bank's market value of equity in million USD. \#Analysts is the number of analysts following a bank. Share_Float \% is the percentage of free float. We retrieve data for MV_Equity, \#Analyst, and Share_Float\% from Thomson Reuters. 


\section{TABLE 4}

Univariate Tests of Institutional Characteristics by Financial_Structure

\begin{tabular}{|c|c|c|c|c|}
\hline Institutional variables & Bank-based & Market-based & Difference & t-stat \\
\hline Value_Traded & 0.13 & 0.45 & 0.32 & $16.15^{* * *}$ \\
\hline Market_Capitalization & 0.24 & 0.69 & 0.45 & $18.57^{* * *}$ \\
\hline \#Analysts & 7.05 & 10.46 & 1.67 & $2.00^{* *}$ \\
\hline Share_Float\% & 48.20 & 65.52 & 17.32 & $8.38^{* * * *}$ \\
\hline Reg_Qual & 0.83 & 0.99 & 0.16 & $3.85^{* * * *}$ \\
\hline Disclosure & 0.42 & 0.62 & 0.20 & $18.99 * * *$ \\
\hline News & 183.51 & 260.97 & 77.46 & $7.75^{* * *}$ \\
\hline$T V \%$ & 86.55 & 95.34 & 8.79 & $5.60^{* * *}$ \\
\hline Institutional Shareholders\% & 13.77 & 16.59 & 2.82 & $1.96^{*}$ \\
\hline Nordic Institutional Shareholders\% & 0.49 & 2.72 & 2.23 & $6.59^{* * * *}$ \\
\hline
\end{tabular}

Panel B: Mean and median fair value assets (liabilities) as a percentage of total assets (liabilities) by Financial_Structure

\begin{tabular}{|c|c|c|c|c|c|c|c|}
\hline & \multicolumn{4}{|c|}{ Financial Assets at Fair Value } & \multicolumn{3}{|c|}{ Financial Liabilities at Fair Value } \\
\hline & HFTA & FVOA & $A F S$ & Total_FVA & HFTL & FVOL & Total_FVL \\
\hline \multicolumn{8}{|c|}{ Bank-based } \\
\hline Mean & $4.5 \%$ & $1.6 \%$ & $8.3 \%$ & $14.4 \%$ & $2.3 \%$ & $1.8 \%$ & $4.1 \%$ \\
\hline Median & $1.5 \%$ & $0.0 \%$ & $5.9 \% * *$ & $9.3 \%$ & $0.3 \%$ & $0.0 \%$ & $0.4 \%$ \\
\hline $\mathrm{N}$ & 319 & 319 & 319 & 319 & 319 & 319 & 319 \\
\hline \multicolumn{8}{|c|}{ Market-based } \\
\hline Mean & $7.2 \% * * *$ & $4.0 \% * * *$ & $7.4 \%$ & $18.6 \% * * *$ & $3.6 \% * *$ & $3.2 \% *$ & $6.8 \% * * *$ \\
\hline Median & $2.2 \% * *$ & $0.3 \% * * *$ & $4.7 \%$ & $14.5 \% * * *$ & $0.5 \% *$ & $0.0 \% * * *$ & $0.9 \% * * *$ \\
\hline $\mathrm{N}$ & 588 & 588 & 588 & 588 & 588 & 588 & 588 \\
\hline \multicolumn{8}{|l|}{ Total } \\
\hline Mean & $6.2 \%$ & $3.2 \%$ & $7.7 \%$ & $17.1 \%$ & $3.2 \%$ & $2.7 \%$ & $5.9 \%$ \\
\hline Median & $1.9 \%$ & $0.1 \%$ & $5.1 \%$ & $12.8 \%$ & $0.4 \%$ & $0.0 \%$ & $0.6 \%$ \\
\hline $\mathrm{N}$ & 907 & 907 & 907 & 907 & 907 & 907 & 907 \\
\hline
\end{tabular}

This table presents summary statistics for institutional characteristics and for proportional fair values partitioned by Financial_Structure. Panel A reports mean values of various institutional variables by Financial_Structure. Panel B presents mean and median proportions of fair value categories partitioned by Financial_Structure. Regulatory quality (Reg_Qual) is constructed as in Kaufmann et al. (2009) using World Bank data. Disclosure is an index from La Porta et al. (2006) measuring the level of disclosure requirements in security offerings. News is the countries' number of newspapers per 1,000 people (source: World Development Indicators, 2012). TV\% is the percentage of households with television in percent (source: World Development Indicators, 2012). Institutional Shareholders\% (Nordic Institutional Shareholders\%) is the percentage of shares held by (Nordic) institutional shareholders in percent. All other institutional characteristics and Financial_Structure are defined in Table 3. HFTA, HFTL, FVOA, FVOL, AFS, Total_FVA, and Total_FVL are defined in Table 2.***,**, and * indicate that the means (medians) are significantly different at the $1 \%, 5 \%$, and $10 \%$ levels, respectively, using a two-tailed $t$-test (Mann-Whitney-Wilcoxon test). 
TABLE 5

Value Relevance of Fair Values in Market-based versus Bank-based Economies

\begin{tabular}{|c|c|c|c|c|c|c|c|}
\hline \multirow{2}{*}{\multicolumn{3}{|c|}{ Dependent variable: $P R I C E$ (USD) }} & \multicolumn{2}{|l|}{ Column (A) } & \multicolumn{3}{|c|}{ Column (B) } \\
\hline & & & \multicolumn{2}{|c|}{ Coefficient es timates, t-stats } & \multicolumn{3}{|c|}{ F-stat, coefficient $=1 /-1$} \\
\hline Variable & Predicted sign & Full sample & Market-based & Bank-based & Full sample & Market-based & Bank-based \\
\hline FVOA_PS & + & $\begin{array}{l}0.709 * * * \\
(6.26)\end{array}$ & $\begin{array}{l}0.840 * * * \\
(9.92)\end{array}$ & $\begin{array}{l}0.249 \\
(0.92)\end{array}$ & $\begin{array}{l}6.60 * * \\
(0.011)\end{array}$ & $\begin{array}{l}3.55^{*} \\
(0.062)\end{array}$ & $\begin{array}{l}7.62 * * * \\
(0.007)\end{array}$ \\
\hline$H F T A \_P S$ & + & $\begin{array}{l}0.964 * * * \\
(7.69)\end{array}$ & $\begin{array}{l}1.001 * * * \\
(8.82)\end{array}$ & $\begin{array}{l}1.034 * * * \\
(4.34)\end{array}$ & $\begin{array}{l}0.08 \\
(0.774)\end{array}$ & $\begin{array}{l}0.00 \\
(0.995)\end{array}$ & $\begin{array}{l}0.02 \\
(0.886)\end{array}$ \\
\hline$A F S \_P S$ & + & $\begin{array}{l}0.826^{* * * *} \\
(7.14)\end{array}$ & $\begin{array}{l}0.880 * * * \\
(8.94)\end{array}$ & $\begin{array}{l}0.652 * * \\
(2.32)\end{array}$ & $\begin{array}{l}2.27 \\
(0.134)\end{array}$ & $\begin{array}{l}1.49 \\
(0.224)\end{array}$ & $\begin{array}{l}1.53 \\
(0.219)\end{array}$ \\
\hline$O A \_P S$ & + & $\begin{array}{l}0.773 * * * \\
(6.96)\end{array}$ & $\begin{array}{l}0.804 * * * \\
(10.91)\end{array}$ & $\begin{array}{l}0.737 * * * \\
(2.93)\end{array}$ & $\begin{array}{l}4.17 * * \\
(0.042)\end{array}$ & $\begin{array}{l}7.09 * * * \\
(0.009)\end{array}$ & $\begin{array}{l}1.09 \\
(0.298)\end{array}$ \\
\hline FVOL_PS & - & $\begin{array}{l}-0.916^{* * *} \\
(-7.67)\end{array}$ & $\begin{array}{l}-0.956^{* * *} \\
(-11.94)\end{array}$ & $\begin{array}{l}-0.620 * * \\
(-2.60)\end{array}$ & $\begin{array}{l}0.50 \\
(0.481)\end{array}$ & $\begin{array}{l}0.31 \\
(0.579)\end{array}$ & $\begin{array}{l}2.54 \\
(0.115)\end{array}$ \\
\hline$H F T L \_P S$ & - & $\begin{array}{l}-0.995 * * * \\
(-7.80)\end{array}$ & $\begin{array}{l}-1.010^{* * * *} \\
(-8.20)\end{array}$ & $\begin{array}{l}-1.079 * * * \\
(-4.65)\end{array}$ & $\begin{array}{l}0.00 \\
(0.966)\end{array}$ & $\begin{array}{l}0.01 \\
(0.935)\end{array}$ & $\begin{array}{l}0.11 \\
(0.736)\end{array}$ \\
\hline$O L \_P S$ & - & $\begin{array}{l}-0.783^{* * *} \\
(-6.70)\end{array}$ & $\begin{array}{l}-0.840^{* * * *} \\
(-10.61)\end{array}$ & $\begin{array}{l}-0.712 * * * \\
(-2.66)\end{array}$ & $\begin{array}{l}3.44 * \\
(0.065)\end{array}$ & $\begin{array}{l}4.06 * * \\
(0.046)\end{array}$ & $\begin{array}{l}1.16 \\
(0.284)\end{array}$ \\
\hline NI_PS & + & $\begin{array}{l}1.797 * * * \\
(3.06)\end{array}$ & $\begin{array}{l}1.975 * * * \\
(2.61)\end{array}$ & $\begin{array}{l}1.755^{* *} \\
(2.37)\end{array}$ & & & \\
\hline Y07 & - & $\begin{array}{l}-8.424 * * * \\
(-7.71)\end{array}$ & $\begin{array}{l}-8.254 * * * \\
(-6.75)\end{array}$ & $\begin{array}{l}-9.032 * * * \\
(-4.18)\end{array}$ & & & \\
\hline Y08 & - & $\begin{array}{l}-14.026^{* * *} \\
(-9.01)\end{array}$ & $\begin{array}{l}-11.161^{* * *} \\
(-8.25)\end{array}$ & $\begin{array}{l}-21.145^{* * *} \\
(-5.14)\end{array}$ & & & \\
\hline Y09 & - & $\begin{array}{l}-10.972 * * * \\
(-7.27)\end{array}$ & $\begin{array}{l}-9.073 * * * \\
(-5.78)\end{array}$ & $\begin{array}{l}-15.725^{* * *} \\
(-4.50)\end{array}$ & & & \\
\hline Intercept & $?$ & $\begin{array}{l}-3.206 \\
(-0.31)\end{array}$ & $\begin{array}{l}23.933^{* * * *} \\
(9.54)\end{array}$ & $\begin{array}{l}-14.193 \\
(-1.04)\end{array}$ & & & \\
\hline $\mathrm{N}$ & & 907 & 588 & 319 & & & \\
\hline Adjusted R- & uared & 0.749 & 0.743 & 0.767 & & & \\
\hline Country fixe & effects & Yes & Yes & Yes & & & \\
\hline \multicolumn{2}{|c|}{ Coefficient comparis on } & F-stat & \multicolumn{5}{|c|}{ p-value } \\
\hline \multirow{4}{*}{\multicolumn{2}{|c|}{$\begin{array}{l}F V O A \_P S=H F T A \_P S \\
F V O A \_P S=A F S \_P S \\
A F S \_P S=H F T A \_P S \\
F V O L \_P S=H F T L \_P S\end{array}$}} & $18.77 * * *$ & $6.23 * *$ & $27.69 * * *$ & $(0.000)$ & $(0.014)$ & $(0.000)$ \\
\hline & & $7.66^{* * *}$ & 0.60 & $12.99 * * *$ & $(0.001)$ & $(0.439)$ & $(0.001)$ \\
\hline & & $5.22 * *$ & $2.76^{*}$ & $9.05 * * *$ & $(0.023)$ & (0.099) & $(0.004)$ \\
\hline & & 2.45 & 0.34 & $14.90 * * *$ & (0.119) & $(0.561)$ & $(0.000)$ \\
\hline \multicolumn{8}{|c|}{$\begin{array}{l}\text { Column (A) reports OLS coefficient estimates and, in parentheses, } t \text {-statistics based on heteroskedasticity-robust standard errors clustered by bank (Rogers, 1993). } \\
\text { Column (B) provides } F \text {-statistics and } p \text {-values in parentheses. PRICE is defined as the market value of equity as of March } 31 \text { of the subsequent financial year (e.g., } \\
\text { March 31, 2007, for the financial year 2006).FVOA_PS, HFTA_PS, and AFS_PS are FVO assets, HFT assets, and AFS assets, respectively, as of December } 31 . O A \_P S \text { are } \\
\text { non-fair value assets as of December 31. FVOL_PS and HFTL_PS are FVO liabilities and HFT liabilities, respectively, as of December } 31 . O L \_P S \text { are non-fair value } \\
\text { liabilities as of December } 31 . N I \_P S \text { is the net income for the financial year. We scale all variables by the number of outstanding shares (Barth and Clinch } 2009 \text { ), and we } \\
\text { denominate values in U.S. Dollars.We include country fixed effects in each regression. } Y 07, Y 08 \text {, and } Y 09 \text { are indicator variables for the years } 2007,2008 \text {, and } 2009 \text {, } \\
\text { respectively. ***,*, and * indicate statistical significance at the } 1 \%, 5 \% \text {, and } 10 \% \text { levels (two-tailed), respectively. }\end{array}$} \\
\hline
\end{tabular}




\section{TABLE 6}

The Role of the Firm-level Information Environment

Dependent variable: PRICE (USD)

Inte raction variable:

\begin{tabular}{|c|c|c|c|c|}
\hline \multirow{2}{*}{ Variable } & \multirow[b]{2}{*}{ Predicted sign } & \\
\hline & & Full sample & Market-based & Bank-based \\
\hline FVOA_PS & + & $\begin{array}{l}0.704 * * * \\
(6.04)\end{array}$ & $\begin{array}{l}0.856 * * * \\
(10.45)\end{array}$ & $\begin{array}{l}0.179 \\
(0.67)\end{array}$ \\
\hline HFTA_PS & + & $\begin{array}{l}0.993 * * * \\
(7.33)\end{array}$ & $\begin{array}{l}0.984 * * * \\
(9.46)\end{array}$ & $\begin{array}{l}1.101 * * * \\
(3.60)\end{array}$ \\
\hline$A F S \_P S$ & + & $\begin{array}{l}0.769 * * * \\
(6.92)\end{array}$ & $\begin{array}{l}0.781 * * * \\
(5.16)\end{array}$ & $\begin{array}{l}0.768 * * \\
(2.49)\end{array}$ \\
\hline$O A \_P S$ & + & $\begin{array}{l}0.784 * * * \\
(6.64)\end{array}$ & $\begin{array}{l}0.853 * * * \\
(11.92)\end{array}$ & $\begin{array}{l}0.839 * * * \\
(2.84)\end{array}$ \\
\hline$F V O L \_P S$ & - & $\begin{array}{l}-0.922^{* * * *} \\
(-7.29)\end{array}$ & $\begin{array}{l}-0.995 * * * \\
(-13.15)\end{array}$ & $\begin{array}{l}-0.830 * * \\
(-2.36)\end{array}$ \\
\hline$H F T L \_P S$ & - & $\begin{array}{l}-0.931 * * * \\
(-5.97)\end{array}$ & $\begin{array}{l}-1.047 * * * \\
(-7.94)\end{array}$ & $\begin{array}{l}-1.104^{* * *} \\
(-3.19)\end{array}$ \\
\hline$O L \_P S$ & - & $\begin{array}{l}-0.794 * * * \\
(-6.45)\end{array}$ & $\begin{array}{l}-0.885^{* * *} \\
(-11.65)\end{array}$ & $\begin{array}{l}-0.821 * * * \\
(-2.66)\end{array}$ \\
\hline$N I \_P S$ & + & $\begin{array}{l}1.829 * * * \\
(2.99)\end{array}$ & $\begin{array}{l}1.876^{* *} \\
(2.46)\end{array}$ & $\begin{array}{l}1.978 * * \\
(2.55)\end{array}$ \\
\hline High_Info & $?$ & $\begin{array}{l}1.081 \\
(0.67)\end{array}$ & $\begin{array}{l}-0.101 \\
(-0.06)\end{array}$ & $\begin{array}{l}0.607 \\
(0.15)\end{array}$ \\
\hline FVOA_PS*High_Info & + & $\begin{array}{l}0.107 * \\
(1.72)\end{array}$ & $\begin{array}{l}0.077 \\
(1.51)\end{array}$ & $\begin{array}{l}0.459 * \\
(1.84)\end{array}$ \\
\hline HFTA_PS*High_Info & + & $\begin{array}{l}-0.092 * * \\
(-2.41)\end{array}$ & $\begin{array}{l}0.045 \\
(0.55)\end{array}$ & $\begin{array}{l}-0.065 \\
(-1.08)\end{array}$ \\
\hline$A F S \_P S * H i g h \_I n f o$ & + & $\begin{array}{l}0.071 \\
(0.77)\end{array}$ & $\begin{array}{l}0.146 \\
(0.97)\end{array}$ & $\begin{array}{l}0.001 \\
(0.01)\end{array}$ \\
\hline $\mathrm{N}$ & & 907 & 588 & 319 \\
\hline Adjusted R-squared & & 0.756 & 0.746 & 0.771 \\
\hline Country fixed effects & & Yes & Yes & Yes \\
\hline Year fixed effects & & Yes & Yes & Yes \\
\hline Intercept & & Yes & Yes & Yes \\
\hline Coefficient comparison & & F-stat & & \\
\hline$F V O A \_P S=1$ & & $6.47 * *$ & $3.08 *$ & $9.33^{* * *}$ \\
\hline$H F T A \_P S=1$ & & 0.00 & 0.02 & 0.11 \\
\hline$A F S \_P S=1$ & & $4.32 * *$ & 2.09 & 0.56 \\
\hline$F V O A \_P S+F V O A \_P S * H i g h \_I n f o=1$ & & 2.04 & 0.59 & 0.93 \\
\hline$H F T A \_P S+H F T A \_P S * H i g h \_i n f o=1$ & & 0.46 & 0.06 & 0.01 \\
\hline$A F S \_P S+A F S \_P S * H i g h \_i n f o=1$ & & 1.51 & 0.63 & 0.54 \\
\hline
\end{tabular}

The table reports OLS coefficient estimates and, in parentheses, $t$-statistics based on heteroskedasticity-robust standard errors clustered by bank (Rogers, 1993). High_Info is a binary variable equal to 1 if a bank has both above median analyst following (\#Analysts) and above median market value of equity (MV_Equity); and 0 otherwise. FVOA_PS*High_Info $H F T A \_P S^{*} H i g h \_I n f o$, and $A F S \_P S * H i g h \_I n f o$ are interaction terms between High_Info and fair value asset classifications. See Table 5 for the definition of all other variables. We include country fixed effects, year fixed effects, and an intercept in each regression. $* * * * *$, and $*$ indicate statistical significance at the $1 \%, 5 \%$, and $10 \%$ levels (two-tailed), respectively.

Coefficient estimates, t-stats

High_Info 


\section{TABLE 7}

The Influence of Institutional Investors

\begin{tabular}{|c|c|c|c|c|c|c|c|}
\hline \multicolumn{2}{|c|}{$\begin{array}{l}\text { Dependent variable: PRICE (USD) } \\
\text { Partitioning variable: }\end{array}$} & \multicolumn{3}{|c|}{$\begin{array}{l}\text { Coefficient estimates, t-stats } \\
\text { (A) Institutional shareholders }\end{array}$} & \multicolumn{3}{|c|}{$\begin{array}{l}\text { Coefficient estimates, t-stats } \\
\text { (B) Nordic Institutional shareholders }\end{array}$} \\
\hline Variable & Predicted sign & Full sample & Market-based & Bank-based & Full sample & Market-based & Bank-based \\
\hline$F V O A \_P S$ & + & $\begin{array}{l}0.690 * * * \\
(4.44)\end{array}$ & $\begin{array}{l}0.811 * * * \\
(5.96)\end{array}$ & $\begin{array}{l}0.414 \\
(1.08)\end{array}$ & $\begin{array}{l}0.393 \\
(1.46)\end{array}$ & $\begin{array}{l}1.046 * * * \\
(5.50)\end{array}$ & $\begin{array}{l}-0.280 \\
(-0.77)\end{array}$ \\
\hline HFTA_PS & + & $\begin{array}{l}0.877 \text { *** } \\
(4.97)\end{array}$ & $\begin{array}{l}0.956^{* * * *} \\
(5.79)\end{array}$ & $\begin{array}{l}0.872^{* * * *} \\
(3.20)\end{array}$ & $\begin{array}{l}0.949 * * * \\
(4.73)\end{array}$ & $\begin{array}{l}0.886^{* * * *} \\
(5.12)\end{array}$ & $\begin{array}{l}0.964 * * * \\
(2.84)\end{array}$ \\
\hline$A F S \_P S$ & + & $\begin{array}{l}0.813^{* * * *} \\
(5.01)\end{array}$ & $\begin{array}{l}0.778 * * * \\
(4.82)\end{array}$ & $\begin{array}{l}0.698^{* *} \\
(2.15)\end{array}$ & $\begin{array}{l}0.802 * * * \\
(4.75)\end{array}$ & $\begin{array}{l}1.226 * * * \\
(5.75)\end{array}$ & $\begin{array}{l}0.740 * * \\
(2.48)\end{array}$ \\
\hline$O A \_P S$ & + & $\begin{array}{l}0.745^{* * * *} \\
(5.16)\end{array}$ & $\begin{array}{l}0.804 * * * \\
(6.76)\end{array}$ & $\begin{array}{l}0.734 * * * \\
(2.69)\end{array}$ & $\begin{array}{l}0.710^{* * * *} \\
(4.08)\end{array}$ & $\begin{array}{l}0.818^{* * * *} \\
(6.46)\end{array}$ & $\begin{array}{l}0.711^{* *} \\
(2.30)\end{array}$ \\
\hline$F V O L \_P S$ & - & $\begin{array}{l}-0.882 * * * \\
(-5.62)\end{array}$ & $\begin{array}{l}-0.938^{* * * *} \\
(-7.02)\end{array}$ & $\begin{array}{l}-0.610^{* *} \\
(-2.17)\end{array}$ & $\begin{array}{l}-0.842^{* * * *} \\
(-4.38)\end{array}$ & $\begin{array}{l}-0.960 * * * \\
(-6.71)\end{array}$ & $\begin{array}{l}-0.558^{*} \\
(-1.75)\end{array}$ \\
\hline$H F T L \_P S$ & - & $\begin{array}{l}-1.008 * * * \\
(-5.96)\end{array}$ & $\begin{array}{l}-1.004 * * * \\
(-5.30)\end{array}$ & $\begin{array}{l}-1.058 * * * \\
(-4.01)\end{array}$ & $\begin{array}{l}-0.908 * * * \\
(-4.11)\end{array}$ & $\begin{array}{l}-1.029 * * * \\
(-5.14)\end{array}$ & $\begin{array}{l}-0.969 * * \\
(-2.52)\end{array}$ \\
\hline$O L \_P S$ & - & $\begin{array}{l}-0.753 * * * * \\
(-4.89)\end{array}$ & $\begin{array}{l}-0.835 \text { **** } \\
(-6.54)\end{array}$ & $\begin{array}{l}-0.705^{* *} \\
(-2.43)\end{array}$ & $\begin{array}{l}-0.718^{* * * *} \\
(-3.94)\end{array}$ & $\begin{array}{l}-0.853 * * * \\
(-6.25)\end{array}$ & $\begin{array}{l}-0.682^{* *} \\
(-2.12)\end{array}$ \\
\hline$N I \_P S$ & + & $\begin{array}{l}1.676 * * * \\
(2.70)\end{array}$ & $\begin{array}{l}1.654 * * \\
(2.18)\end{array}$ & $\begin{array}{l}1.920 * * \\
(2.20)\end{array}$ & $\begin{array}{l}1.768 * * * \\
(2.80)\end{array}$ & $\begin{array}{l}1.607 * * \\
(2.14)\end{array}$ & $\begin{array}{l}2.198 * * \\
(2.17)\end{array}$ \\
\hline INST & $?$ & $\begin{array}{l}0.694 \\
(0.37)\end{array}$ & $\begin{array}{l}-2.465 \\
(-1.56)\end{array}$ & $\begin{array}{l}5.541 \\
(1.52)\end{array}$ & $\begin{array}{l}1.213 \\
(0.63)\end{array}$ & $\begin{array}{l}1.450 \\
(0.86)\end{array}$ & $\begin{array}{l}4.030 \\
(1.19)\end{array}$ \\
\hline$F V O A \_P S * I N S T$ & + & $\begin{array}{l}-0.065 \\
(-1.02)\end{array}$ & $\begin{array}{l}0.050 \\
(1.58)\end{array}$ & $\begin{array}{l}-0.186 \\
(-0.83)\end{array}$ & $\begin{array}{l}0.258 \\
(0.94)\end{array}$ & $\begin{array}{l}-0.207 \\
(-1.64)\end{array}$ & $\begin{array}{l}0.624 * * \\
(2.33)\end{array}$ \\
\hline HFTA_PS*INST & + & $\begin{array}{l}0.097 \\
(1.64)\end{array}$ & $\begin{array}{l}0.034 \\
(0.76)\end{array}$ & $\begin{array}{l}0.147 \\
(1.43)\end{array}$ & $\begin{array}{l}-0.067 * * \\
(-2.12)\end{array}$ & $\begin{array}{l}\mathbf{0 . 1 3 5} * * * \\
(\mathbf{3 . 0 2})\end{array}$ & $\begin{array}{l}-0.051 \\
(-0.92)\end{array}$ \\
\hline$A F S \_P S^{*} I N S T$ & + & $\begin{array}{l}-0.008 \\
(-0.10)\end{array}$ & $\begin{array}{l}0.097 \\
(0.91)\end{array}$ & $\begin{array}{l}-0.053 \\
(-0.40)\end{array}$ & $\begin{array}{l}-0.032 \\
(-0.25)\end{array}$ & $\begin{array}{l}-0.360 * * \\
(-2.30)\end{array}$ & $\begin{array}{l}-0.117 \\
(-1.06)\end{array}$ \\
\hline \multicolumn{2}{|l|}{$\mathrm{N}$} & 688 & 450 & 238 & 688 & 450 & 238 \\
\hline \multicolumn{2}{|l|}{ Adjusted R-squared } & 0.752 & 0.727 & 0.786 & 0.758 & 0.729 & 0.793 \\
\hline \multicolumn{2}{|l|}{ Country fixed effects } & Yes & Yes & Yes & Yes & Yes & Yes \\
\hline \multicolumn{2}{|l|}{ Year fixed effects } & Yes & Yes & Yes & Yes & Yes & Yes \\
\hline \multicolumn{2}{|l|}{ Intercept } & Yes & Yes & Yes & Yes & Yes & Yes \\
\hline \multicolumn{2}{|c|}{ Coefficient comparis on } & F-stat & & & F-stat & & \\
\hline \multicolumn{2}{|c|}{$F V O A \_P S=1$} & $3.99 * *$ & 1.91 & 2.33 & $5.09 * *$ & 0.06 & $12.38 * * *$ \\
\hline \multicolumn{2}{|l|}{$H F T A \_P S=1$} & 0.49 & 0.07 & 0.22 & 0.07 & 0.43 & 0.01 \\
\hline \multicolumn{2}{|l|}{$A F S \_P S=1$} & 1.33 & 1.89 & 0.86 & 1.38 & 1.12 & 0.76 \\
\hline \multirow{3}{*}{\multicolumn{2}{|c|}{$\begin{array}{l}F V O A \_P S+F V O A \_P S * I N S T=1 \\
H F T A \_P S+H F T A \_P S * I N S T=1 \\
A F S \_P S+A F S \_P S * I N S T=1\end{array}$}} & $6.03^{* *}$ & 0.97 & $6.31 * *$ & $3.87 *$ & 1.22 & $5.29 * *$ \\
\hline & & 0.02 & 0.00 & 0.01 & 0.32 & 0.01 & 0.05 \\
\hline & & 1.75 & 1.02 & 1.39 & 1.44 & 0.91 & 1.30 \\
\hline
\end{tabular}


TABLE 8

Fair Value Categories and Measurement Inputs

\begin{tabular}{|c|c|c|c|c|c|c|c|c|}
\hline \multirow[b]{2}{*}{ Variable } & \multicolumn{2}{|c|}{ Full sample } & \multicolumn{2}{|c|}{ Market-based } & \multicolumn{2}{|c|}{ Bank-based } & \multicolumn{2}{|c|}{ Market vs. Bank } \\
\hline & Mean & Median & Mean & Median & Mean & Median & $t$-stat & $z$-stat \\
\hline \multicolumn{9}{|l|}{ FVO } \\
\hline Levell & $45.88 \%$ & $48.96 \%$ & $48.73 \%$ & $52.96 \%$ & $40.88 \%$ & $41.70 \%$ & -1.13 & -1.27 \\
\hline Level2 & $45.40 \%$ & $44.68 \%$ & $41.26 \%$ & $37.00 \%$ & $52.64 \%$ & $48.01 \%$ & 1.68 & $1.85^{*}$ \\
\hline Level3 & $8.73 \%$ & $0.20 \%$ & $10.01 \%$ & $0.49 \%$ & $6.48 \%$ & $0.00 \%$ & -1.00 & -1.10 \\
\hline \multicolumn{9}{|l|}{ HFT } \\
\hline Levell & $35.03 \%$ & $29.00 \%$ & $39.76 \%$ & $32.56 \%$ & $26.77 \%$ & $17.64 \%$ & $-2.43^{* *}$ & -2.39 ** \\
\hline Level2 & $61.48 \%$ & $66.35 \%$ & $57.07 \%$ & $64.23 \%$ & $69.20 \%$ & $78.02 \%$ & $2.30 * *$ & $2.25^{* *}$ \\
\hline Level3 & $3.49 \%$ & $0.46 \%$ & $3.17 \%$ & $0.54 \%$ & $4.03 \%$ & $0.11 \%$ & 0.66 & -0.51 \\
\hline \multicolumn{9}{|l|}{ AFS } \\
\hline Levell & $59.74 \%$ & $71.00 \%$ & $56.59 \%$ & $70.03 \%$ & $65.24 \%$ & $76.06 \%$ & 1.42 & 1.16 \\
\hline Level2 & $25.80 \%$ & $15.58 \%$ & $26.22 \%$ & $15.58 \%$ & $25.07 \%$ & $14.80 \%$ & -0.22 & -0.30 \\
\hline Level3 & $14.47 \%$ & $2.51 \%$ & $17.20 \%$ & $3.19 \%$ & $9.69 \%$ & $1.52 \%$ & -1.61 & -1.98 ** \\
\hline $\mathrm{N}$ & 132 & 132 & 84 & 84 & 48 & 48 & & \\
\hline & $t$-stat & $z$-stat & $t$-stat & $z$-stat & $t$-stat & $z$-stat & & \\
\hline \multicolumn{9}{|c|}{ Differences in Level 1} \\
\hline FVO vs. HFT & $2.93 * * *$ & $3.17 * * *$ & $1.91^{*}$ & $2.30^{* *}$ & $2.34 * *$ & $2.27^{* *}$ & & \\
\hline FVO vs. AFS & $-3.45^{* * *}$ & $-2.97 * * *$ & -1.55 & -0.82 & $-3.83 * * *$ & $-3.39 * * *$ & & \\
\hline HFT vs. AFS & $-6.88 * * *$ & $-6.18^{* * *}$ & $-3.66^{* * *}$ & $-3.64 * * *$ & $-7.38 * * *$ & $-5.25 * * *$ & & \\
\hline \multicolumn{9}{|c|}{ Differences in Level 2} \\
\hline FVO vs. HFT & $-4.39^{* * *}$ & $-4.49 * * *$ & $-3.51^{* * * *}$ & $-3.82 * * *$ & $-2.60 * *$ & $-2.52^{* *}$ & & \\
\hline FVO vs. AFS & $5.07 * * *$ & $4.28 * * *$ & $3.05 * * *$ & $2.29^{* *}$ & $4.53 * * *$ & $3.77^{* * * *}$ & & \\
\hline HFT vs. AFS & $10.40 * * *$ & $7.99 * * *$ & $6.73 * * *$ & $5.75 * * *$ & $9.21 * * *$ & $5.64 * * *$ & & \\
\hline \multicolumn{9}{|c|}{ Differences in Level 3} \\
\hline FVO vs. HFT & $3.02 * * *$ & -1.10 & $2.89 * * *$ & $-1.86^{*}$ & 1.05 & -0.68 & & \\
\hline FVO vs. AFS & $-2.04 * *$ & $-2.94 * * *$ & $-1.81 *$ & $-2.61 * * *$ & -0.94 & -1.30 & & \\
\hline HFT vs. AFS & $-4.82^{* * * *}$ & $-4.85^{* * *}$ & $-4.31^{* * * *}$ & $-4.61 * * *$ & $-2.29 * *$ & $-1.98 * *$ & & \\
\hline
\end{tabular}


TABLE 8 (continued)

Panel B: Regression with focus on Level 1 assets

Dependent variable: $P R I C E$ (USD)

Coefficient estimates, $t$-s tats

F-stat, coefficient $=1$

Variable

Predicted sign

Full sample Market-based Bank-based

Full sample Market-based Bank-based

\begin{tabular}{|c|c|c|c|c|c|c|c|}
\hline$L 1 \_F V O A \_P S$ & + & $\begin{array}{l}0.593 * * * \\
(6.80)\end{array}$ & $\begin{array}{l}0.722 * * * \\
(6.22)\end{array}$ & $\begin{array}{l}0.498 \\
(1.60)\end{array}$ & $21.83^{* * *}$ & $5.71 * *$ & 2.60 \\
\hline L1_HFTA_PS & + & $\begin{array}{l}0.805^{* * * *} \\
(7.99)\end{array}$ & $\begin{array}{l}0.897 * * * \\
(6.06)\end{array}$ & $\begin{array}{l}0.732 * * * \\
(3.42)\end{array}$ & $3.73^{*}$ & 0.48 & 1.57 \\
\hline$L 1 \_A F S \_P S$ & + & $\begin{array}{l}1.021 * * * \\
(11.22)\end{array}$ & $\begin{array}{l}0.966 * * * \\
(6.50)\end{array}$ & $\begin{array}{l}1.402 * * * \\
(8.12)\end{array}$ & 0.05 & 0.05 & $5.43 * *$ \\
\hline$O A \_L 1 \_P S$ & + & $\begin{array}{l}0.832 * * * \\
(11.43)\end{array}$ & $\begin{array}{l}0.830 * * * \\
(6.68)\end{array}$ & $\begin{array}{l}1.053 * * * \\
(7.85)\end{array}$ & $5.36^{* *}$ & 1.88 & 0.16 \\
\hline$F V O L \_P S$ & - & $\begin{array}{l}-0.764 * * * \\
(-10.29)\end{array}$ & $\begin{array}{l}-0.822 * * * \\
(-7.50)\end{array}$ & $\begin{array}{l}-0.951 * * * \\
(-5.88)\end{array}$ & & & \\
\hline$H F T L \_P S$ & - & $\begin{array}{l}-0.848^{* * *} \\
(-11.65)\end{array}$ & $\begin{array}{l}-0.852 * * * \\
(-6.87)\end{array}$ & $\begin{array}{l}-1.022 * * * \\
(-8.99)\end{array}$ & & & \\
\hline$O L \_P S$ & - & $\begin{array}{l}-0.842^{* * *} \\
(-11.02)\end{array}$ & $\begin{array}{l}-0.854 * * * \\
(-6.43)\end{array}$ & $\begin{array}{l}-1.074 * * * \\
(-7.63)\end{array}$ & & & \\
\hline$N I \_P S$ & + & $\begin{array}{l}1.543 * * * \\
(3.80)\end{array}$ & $\begin{array}{l}1.193 * * \\
(2.06)\end{array}$ & $\begin{array}{l}2.179 * * * \\
(4.40)\end{array}$ & & & \\
\hline Y08 & - & $\begin{array}{l}-2.086 * * \\
(-2.46)\end{array}$ & $\begin{array}{l}-2.038 * * \\
(-2.23)\end{array}$ & $\begin{array}{l}-1.758 \\
(-0.90)\end{array}$ & & & \\
\hline $\mathrm{N}$ & & 278 & 183 & 95 & & & \\
\hline Adjusted R-squared & & 0.894 & 0.796 & 0.946 & & & \\
\hline Country fixed effects & & Yes & Yes & Yes & & & \\
\hline Intercept & & Yes & Yes & Yes & & & \\
\hline Coefficient comparis on & & F-stat & & & & & \\
\hline L1_FVOA_PS = L1_HFTA_PS & & $3.70 *$ & 2.17 & 0.23 & & & \\
\hline$L 1 \_F V O A \_P S=L 1 \_A F S \_P S$ & & $19.12 * * *$ & $5.34 * *$ & $6.68 * *$ & & & \\
\hline L1_HFTA_PS $=L 1 \_A F S \_P S$ & & $3.53 *$ & 0.27 & $8.34 * * *$ & & & \\
\hline
\end{tabular}

Panel A presents mean and median proportions of Level 1, 2, and 3 valuation inputs across fair value categories and institutional environments. Levell $(F V O)$ is the proportion of FVO assets measured by reference to a quoted price in an active market (Level 1) to the sum of FVO assets. Level2 (FVO) is the proportion of FVO assets measured with valuation techniques using observable inputs (Level2) to the sum of FVO assets. Level3 (FVO) is the proportion of FVO assets measured with valuation techniques using un observable inputs (Level3) to the sum of FVO assets. The proportions of HFT and AFS assets are analogously calculated. $* * *, * *$, and $*$ indicate that the means (medians) are significantly different at the $1 \%, 5 \%$, and $10 \%$ levels, respectively, using a twotailed $t$-test (Wilcoxon signed rank test) with paired data. For the tests across institutions (i.e., market-based vs. bank-based), we use two-tailed $t$-test (Mann Whitney-Wilcoxon test) to compare means (medians).

Panel B reports OLS coefficient estimates and, in parentheses, $t$-statistics based on heteroskedasticity-robust standard errors clustered by bank (Rogers, 1993).L1_FVOA_PS,L1_HFTA_PS, and L1_AFS_PS are Level 1 FVO, HFT, and AFS assets scaled by the number of outstanding shares and denominated in US Dollars. $O A_{-} L 1 \_P S$ is defined as total assets minus $L 1 \_F V O A_{-} \_S, L 1 \_H F T A \_P S$, and $L 1 \_A F S \_P S$. See Table 5 for the definition of all other variables. $* * *, * *$, and $*$ indicate statistical significance at the $1 \%, 5 \%$, and $10 \%$ levels (two-tailed), respectively. 
TABLE 9

The Quality of Fair Values

\section{Column (A)}

Column (B)

\section{Dependent variable: $F V O \_T A$}

\begin{tabular}{llll} 
Variable & Predicted sign & Market-based & Bank-based \\
& & & $14.635^{* * * *}$ \\
FVO_INC & + & $5.812^{*}$ & $(4.84)$ \\
& & $(1.87)$ & -0.007 \\
Persistent & $?$ & $-0.037^{* *}$ & $(-0.36)$ \\
& & $(-2.38)$ & $10.593^{* * *}$ \\
FVO_INC * Persistent & + & $13.441^{* * *}$ & $(3.61)$ \\
& $?$ & $(3.16)$ & -0.004 \\
Size & & -0.008 & $(-0.71)$ \\
& & $(-1.50)$ & 0.065 \\
Intercept & & $0.138^{* *}$ & $(0.90)$ \\
& & $(2.21)$ & 55 \\
\hline N & & 134 & 0.80 \\
Adjusted R-squared & & 0.29 & 504
\end{tabular}

This table reports OLS coefficient estimates, and, in parentheses, t-statistics based on heteroskedasiticity-robust standard errors clustered by bank (Rogers, 1993). The pooled OLS regressions test the association of fair values of FVO assets with income from FVO assets and with the persistence of FVO income. The dependent variable FVO_TA is FVO assets divided by total assets. FVO_INC is the sum of interest and dividend income from FVO assets and realized gains and losses from the disposal of FVO assets, divided by total assets. Persistent equals 1 for banks with the highest FVO income persistence measured as the highest quartile rank of the estmimated $\beta_{1}$ coefficient from the regression $F V O_{-} I N C_{i t+1}=\beta_{0}+\beta_{1} F V O_{-} I N C_{i t}+\beta_{2} S_{i z e}+\varepsilon_{i t}$, and 0 otherwise. 